\title{
LOS ESTADOS UNIDOS EN LAS CULTURAS CONSTITUCIONALES DEL LIBERALISMO POSTREVOLUCIONARIO ESPAÑOL (1834-1848) 123
}

\section{THE UNITED STATES IN THE CONSTITUTIONAL CULTURES OF SPANISH POSTREVOLUTIONARY LIBERALISM (1834-1848)}

\author{
Rodrigo Escribano Roca \\ Facultad de Artes Liberales de la Universidad Adolfo Ibáñez (UAI) \\ Centro de Estudios Americanos de la Universidad Adolfo Ibáñez (CEA-UAI) \\ Instituto Universitario de Investigación en Estudios Latinoamericanos de la \\ Universidad de Alcalá (IELAT-UAH)
}

\begin{abstract}
SUMARIO: I. INTRODUCCIÓN.- 1.1 Experimentos transatlánticos: breve contexto.- 1.2. Culturas políticas y modelos constitucionales: propuesta teóricometodológica.- II. ESCUELA DE LIBERTAD. EL MODELO ESTADOUNIDENSE EN EL PENSAMIENTO PROGRESISTA.- 2.1. Constitucionalismo de imprenta y movilización exaltada: traducción, edición y exégesis ideológica.- 2.2. Internacionalismo postimperial y municipalismo: la inspiración norteamericana.2.3. Entre la admiración y la cautela: interpretaciones progresistas del constitucionalismo democrático.- III. EL ESPEJO INVERTIDO. LOS ESTADOS UNIDOS EN EL CONSTITUCIONALISMO MODERADO.- 3.1. Tradiciones anglosajonas: la revolución americana desde el historicismo moderado.- 3.2. Democracias opuestas: el constitucionalismo estadounidense y el monarquismo hispanista.-IV.CONCLUSIÓN
\end{abstract}

Palabras clave: Cultura constitucional, Estados Unidos, liberalismo español, progresistas, moderados.

Key Words: Constitutional cultures, United States, Spanish liberalism, exalted liberalism, conservative liberalism.

\section{INTRODUCCIÓN}

La consolidación de un sistema constitucional de corte democrático en los Estados Unidos durante las décadas centrales del siglo XIX afectó decisivamente

\footnotetext{
1 Dedicado a Susana María Roca Valiente, mi primera maestra de pensamiento constitucional y correctora fundamental de este texto.

2 Este trabajo se ha realizado en el marco del Programa Interuniversitario en Cultura de la Legalidad, financiado por la Comunidad de Madrid, con referencia: "H2019/HUM-5699 (ON TRUST-CM). También del Fondecyt de Iniciación financiado por la Agencia Nacional de Investigación y Desarrollo. Ministerio de Ciencia, Tecnología, Conocimiento e Innovación de Chile, con referencia: Fondecyt $\mathrm{N}^{\circ} 112000245$.
}

${ }^{3}$ Gracias a Vicente Bello Fuentes, editor dedicado, desinteresado y eficiente de este escrito 
a las culturas políticas del liberalismo postrevolucionario en España. El artículo estudia cómo las élites intelectuales del progresismo y el moderantismo interpretaron el funcionamiento de las instituciones norteamericanas, construyendo imágenes de estas que fueron funcionales a sus respectivos proyectos politicos. Los relatos en torno al desarrollo constitucional de Estados Unidos actuaron como verdaderos mitos políticos y jurídicos. Estos impactaron decisivamente en la definición de la cultura constitucional de progresistas y moderados. El análisis reconstruirá las pugnas argumentativas en torno al papel que debía tener el modelo estadounidense en la modernización del paisaje constitucional de la Monarquía española.

\subsection{Experimentos transatlánticos: breve contexto}

El trabajo se centrará en las dos décadas que siguieron a la apertura y consolidación de un sistema de gobierno representativo en España, a partir de la promulgación del Estatuto Real del año 1834. Este documento, aprobado bajo el gobierno moderado de Francisco Martínez de la Rosa, institucionalizaba el paso de una Monarquía de corte absolutista a un régimen de carta otorgada que aún permanecía fuertemente tutelado por la Corona ${ }^{4}$. El tímido, aunque decisivo, desarrollo constitucional que el Estatuto había comportado solo había sido posible tras el fallecimiento de Fernando VII en 1833. Su reinado se habia caracterizado por el conflicto con los partidarios del liberalismo político. Estos habían logrado imponer el funcionamiento de un sistema parlamentario durante dos breves periodos (1810-1814; 1820-1823) que habian ido inmediatamente seguidos por una cruda represión absolutista ${ }^{5}$. Sin embargo, la muerte de Fernando VII había ido acompañada de una necesidad repentina de la Corona de abrir un proceso de negociación transicional con los liberales. Este movimiento se debió a la amenaza que Carlos de Borbón, hermano del rey y adalid del tradicionalismo, representaba para la legitimidad de la hija de Fernando, Isabel II, y de su madre, la regente María Cristina ${ }^{6}$.

Dicha apertura, sin embargo, mantuvo unos contornos limitados desde el principio, dándole acceso al poder ejecutivo solo a aquellos elementos del liberalismo hispánico que habian renunciado a una reforma integral de la Monarquía. Ello favoreció a los en adelante llamados "moderados" frente a los liberales "exaltados". Esta última categoría comprendía, al menos en la coyuntura previa a la aprobación de la carta constitucional de 1837, a todos aquellos defensores del gobierno representativo que se mantenían fieles al aparato doctrinal de la Constitución de $1812^{7}$. Ésta había sido redactada por las Cortes constituyentes reunidas en Cádiz durante el cautiverio de Fernando VII en París y la invasión napoleónica de la Península. Desconociendo la autoridad de José I

\footnotetext{
4 Natividad Araque Hontangas, "Las primeras elecciones celebradas con el Estatuto Real de 1834" Cuadernos de historia contemporánea, n³2, 2010, pp. 96-100.

5 Gonzalo Butrón Prida, "Redefinir rey y soberania: el retorno de Fernando VII y la agonía del Liberalismo", Pasado y memoria: Revista de historia contemporánea, n 13, 2014, pp. 59-78.

6 María Sierra, “La Vida Política”, en Jordi Canal (edit.), Historia Contemporánea de España, Fundación Mapfre, Madrid, 2017, pp. 297-303.

7 Joaquín Varela Suanzes-Carpegna, La monarquía doceañista (1810-1837): avatares, encomios y denuestos de una extraña forma de gobierno, Marcial Pons, Madrid, 2013, pp. 385-391.
} 
Bonaparte, las Cortes se habían arrogado temporalmente la soberanía alienada por el rey cautivo y delegada de nuevo por los municipios de la Monarquía, organizados en Juntas ${ }^{8}$.

Las Cortes de Cádiz, siempre convulsionadas por el conflicto entre los defensores del viejo orden político (llamados "serviles") 9 y los adalides del liberalismo de inspiración revolucionaria y contractualista, habían terminado redactando una carta constitucional que reflejaba en buena medida los valores políticos de estos últimos. La Constitución de 1812, llamada popularmente "la Pepa", consagraba el poder soberano del parlamento a través de un sistema unicameral; establecía una fuerte autonomía para las corporaciones municipales y las diputaciones provinciales; abolia las jurisdicciones y regímenes de propiedad de carácter señorial; y reconocía un amplio sufragio para todos los varones adultos de la Monarquía en España y las Américas, con la notable salvedad de los descendientes de africanos. El modelo de monarquía constitucional que derivó de la carta gaditana, si bien se enraizaba en el aparato doctrinal del reformismo ibérico y en las instancias corporativas presentes en el movimiento juntero ${ }^{10}$, ha llegado a ser tachado de "monarquía republicana". Ello por su evidente compromiso con las formas institucionales recetadas por la ilustración radical euroamericana; particularmente por la concentración del poder legislativo y ejecutivo en las Cortes, que se instituían en depositarias de una soberanía nacional que desplazaba la centralidad secular de la Corona como ámbito de legitimidad ${ }^{11}$.

Como se ha mencionado, la vuelta de Fernando VII en 1814 trajo la suspensión del régimen constitucional y la persecución de los liberales. Estos, sin embargo, ya se habian consolidado como un grupo de poder relevante en ciertos círculos mesocráticos de la sociedad civil y en el ejército. Ello facilitó que las logias masónicas cripto-liberales orquestasen un pronunciamiento militar protagonizado por el general Rafael del Riego. Este hecho permitió el restablecimiento de la Constitución de 1812 durante un período de tres años, conocido como el "Trienio Liberal"12. Sin embargo, una nueva reacción monárquica respaldada por la Santa Alianza despojó a estos reformadores del poder. La represión que siguió dio con una buena parte de la intelligentsia liberal

\footnotetext{
8 Dos estudios de autores canónicos sobre el fenómeno: Jaime E. Rodríguez, Political Culture in Spanish America, UNP - Nebraska, Lincoln, 2018, pp. 7-14; Jose Maria Portillo Valdés, Crisis Atlántica: Autonomía e Independencia en la Crisis de la Monarquía Hispana, Marcial Pons, Madrid, 2006, 53-59.

9 Juan Pablo Dominguez, "La idea de España en el discurso "servil" (1808-1814)", Historia y politica: Ideas, procesos y movimientos sociales, n 41, 2019, 177-209.

10 Antoni Moliner i Prada, "Tradición y liberalismo en torno al proceso constitucional gaditano", Trienio: Ilustración y liberalismo, $\mathrm{n}^{\circ}$ 63, 2014, 43-58.

11 Ignacio Fernández Sarasola, "La Constitución de Cádiz: entre historicismo y revolución”, en Segio Sánchez Collantes (edit.), Estudios sobre el republicanismo histórico en España: luchas politicas, constitucionalismo y alcance sociocultural, Real Instituto de Estudios Asturianos, Burgos, 2017, pp. 21-50.

12 Francisco Carantoña Álvarez, "La historiografía sobre el Trienio Liberal: entre el estigma del fracaso y el enfoque militante". Pasado y memoria: Revista de historia contemporánea, $\mathrm{n}^{\circ} 22$, 2021, 19-52.
} 
en el exilio ${ }^{13}$. Durante los años que mediaron entre 1823 y 1833 , los liberales comenzaron su escisión en varias culturas constitucionales diferenciadas, en lo que se ha entendido como el tránsito del primer liberalismo español a los llamados liberalismos postrevolucionarios.

Las dos décadas que siguieron al retorno de los liberales y la aprobación del Estatuto Real en 1834 contemplaron, así, cómo el constitucionalismo y el parlamentarismo se normalizaban en la Monarquía, aunque de manera notablemente conflictiva y accidentada ${ }^{14}$. La disputa por definir la estructura constitucional que debía regir el nuevo sistema de relaciones sociales dio lugar a una tensión irresuelta entre los proyectos político-territoriales de las dos grandes ramas del liberalismo postrevolucionario: como se ha dicho, los liberales progresistas o "exaltados" y los liberales moderados, que a su vez se vieron enfrentados a los sectores antiliberales y a un incipiente movimiento republicano.

Los liberales progresistas propugnaron, a grandes rasgos, la vertebración de una Monarquía parlamentaria, en la cual la Corona debía aceptar el ejercicio del poder legislativo por parte de las Cortes, limitándose a funciones ejecutivas, nombrando a los gabinetes de acuerdo a los equilibrios de poder en el Congreso y respondiendo ante este. Los integrantes del Partido Progresista, liderado por figuras como Agustín Argüelles, José María Calatrava y Juan Álvarez Mendizábal, reiteraron los principios de la soberanía nacional y el municipalismo, asociando ambos a la participación de los grupos populares urbanos en la toma de decisiones politicas. Con todo, frente al proyecto rupturista que habia representado la Constitución de 1812, el progresismo postrevolucionario apostó por un reformismo escalonado, que aumentase paulatinamente las bases de la participación política a través de la acción legislativa ${ }^{15}$.

Los moderados, organizados como partido desde 1835, aspiraron a depurar completamente los elementos revolucionarios y democráticos del constitucionalismo liberal. Encabezados por viejos doceañistas como Andrés Borrego, Francisco Martínez de la Rosa, el Conde de Toreno y Antonio Alcalá Galiano, se aplicaron a sancionar un marco posibilista de libertades económicas y civiles que se armonizase con la expansión y la centralización de la administración del Estado y con el mantenimiento de estructuras de gobernanza corporativa y confesional que garantizasen el orden público y la preeminencia social de las élites mesocráticas y tradicionales ${ }^{16}$. Los moderados aspiraron a

13 Juan Luis Simal, "El exilio en la génesis de la nación y del liberalismo (1776-1848): el enfoque transnacional", Ayer, n 94, 2014, 23-48.

14 Isabel Burdiel, "Las claves del período" en Jordi Canal (edit.), Historia Contemporánea de España, Fundación Mapfre, Madrid, 2017, 267-296.

15 Rafael Zurita, "El Progresismo. Héroes e historia de la nación liberal" en María Cruz Romeo y María Sierra (edit.), La España liberal, 1833-1874, Marcial Pons, Madrid, 2014, pp. 344-347; Antonio Moliner Prada, "Liberalismo y cultura politica liberal en la España del siglo XIX", Revista de História das Ideias, n 37, 2019, 223-227, https://doi.org/10.14195/2183-8925_37_9.

16 Rebeca Viguera Ruiz, "El moderantismo en la etapa postrevolucionaria. Un ejemplo en clave local a comienzos del siglo XIX", Historia constitucional: Revista Electrónica de Historia Constitucional, ${ }^{\circ}$ 14, 2013, pp. 175-176, 189-191; Juan Pro, "El Estado grande de los moderados en la España del siglo XIX”, Historia y politica: Ideas, procesos y movimientos sociales, $\mathrm{n}^{\circ} 36$, 2016, pp. 19-48. 
articular una soberanía compartida entre rey y Cortes y definir una idea restrictiva de la representación ciudadana ${ }^{17}$.

Las divisiones ideológicas entre progresistas y moderados explican que se sucediesen modelos constitucionales muy dispares en su definición de los derechos civiles y políticos de los españoles. La rápida sustitución del Estatuto de 1834 por la Constitución de 1837, de inspiración progresista, y de esta por la Constitución de 1845, depositaria de los valores del moderantismo, fue demostrativa del duelo que las élites políticas del momento establecieron para imponer sus respectivos horizontes normativos ${ }^{18}$. En este contexto, las imágenes interesadas que cada grupo construyó respecto del sistema constitucional americano cobraron una gran importancia doctrinal.

La coyuntura coincidió con la consolidación del experimento políticoterritorial que suponian los Estados Unidos. Las élites euroamericanas de los años treinta debieron hacerse cargo del hecho de que la precaria unión federal que había emergido tras la Declaración de Independencia de 1776 y la Constitución de 1787 había cumplido ya medio siglo. Su durabilidad demostraba que la existencia de un Estado republicano, federado y percibido como democrático no solo era posible, sino que además podía garantizar cuotas inesperadas de prosperidad comercial y de crecimiento demográfico. El éxito del presidente Andrew Jackson, y de sus postulados democratizadores respecto de los derechos políticos de todos los varones blancos de los Estados, se unió a una nueva oleada europea de revoluciones constitucionales democratizadoras a principios de los años 30. Esta, que afectó particularmente a Francia, Bélgica y Polonia, también tuvo sus consecuencias en la reforma electoral aprobada en el Reino Unido en 1832. Estos hechos, como argumentan convincentemente John Garrard y Jonathan Israel, situaron a la república anglosajona en el centro del debate en torno a la modernidad politica de Europa y las Américas de habla hispana ${ }^{19}$. Además, la unidad que les garantizaba a los Estados Unidos el modelo federal, vinculada a su expansión territorial a costa de las poblaciones indígenas, del imperio español y de México, impactó en las concepciones sobre las intersecciones que se daban entre la soberanía nacional, el autonomismo local y la gobernanza de territorios de escala imperial ${ }^{20}$. Por último, la prosperidad de sus relaciones comerciales con el Imperio Británico suscitó entre las élites hispanas una honda reflexión sobre la utilidad de las relaciones postimperiales

17 Fidel Gómez Ochoa, "El liberalismo conservador español del siglo XIX: la forja de una identidad politica, 1810-1840", Historia y politica: Ideas, procesos y movimientos sociales, $\mathrm{n}^{\circ} 17$, 2007, pp. 37-68.

18 Juan Pro Ruiz, La construcción del Estado en España: una historia del siglo XIX, Alianza, Madrid, 2019, 227-289.

19 John Garrard, "The Democratic Experience" in Stefan Berger (edit.), A Companion to Nineteenth-Century Europe, 1789-1914, Blackwell Pub., Malden, Mass., 2006, pp. 149-163; Jonathan Israel, The Expanding Blaze: How the American Revolution Ignited the World, 1775-1848: Princeton University Press, Princeton (New Jersey), 2017, pp. 516-542.

20 Nuria Tabanera García, Historia internacional de América Latina: de las Independencias a la II Guerra Mundial (1776-1945), Sintesis, Madrid, 2018, pp. 65-71; James Belich, Replenishing the Earth: The Settler Revolution and the Rise of the Anglo-World, 1783-1939, Oxford University Press, Oxford; New York 2009, pp. 15-19. 
basadas en el derecho internacional como alternativa válida a los modelos de explotación colonial21.

\subsection{Culturas políticas y modelos constitucionales: propuesta teórico- metodológica}

Todos los elementos mencionados del desarrollo constitucional y geoestratégico de los Estados Unidos afectaron a los imaginarios políticos españoles. Los desarrollos descritos fueron el fermento sobre el cual las élites intelectuales del liberalismo postrevolucionario construyeron relatos ideológicos dispares en torno a los vicios y las virtudes del sistema constitucional estadounidense. Ante todo, trataron de interpretar su influencia en el decurso de las revoluciones constitucionales que habian acontecido en el Atlántico ibérico durante las décadas previas, intentando a su vez inferir las lecciones que el modelo angloamericano arrojaba para el diseño de los órdenes político-jurídicos que debian prevalecer tanto en la Monarquía española como en las repúblicas hispanoamericanas, las cuales, como veremos, seguían conceptuándose como parte de una comunidad hispánica postimperial.

La hipótesis de trabajo es que las élites del progresismo y del moderantismo se aplicaron a una labor compleja de interpretación e instrumentalización del experimento americano con el fin de dotar de poder argumentativo y doctrinal a los relatos legitimadores de sus respectivas culturas constitucionales. Como fue habitual en los procesos de circulación transnacional del constitucionalismo estadounidense 22 , los pensadores políticos del liberalismo postrevolucionario español encabezaron un ejercicio simultáneo de recepción, traducción, utilización y adaptación de los presupuestos doctrinales que le daban cuerpo a la arquitectura institucional angloamericana. Las narrativas de progresistas y moderados en torno a la historia constitucional de la república ultramarina, así como las exégesis del corpus legislativo que había derivado de la misma esencialmente la Declaración de Independencia, la Constitución y la Declaración de Derechos- se convirtieron en un recurso de primer orden para justificar y orientar los horizontes ideológicos que competian en el seno del sistema político español.

Si bien es cierto, como han dejado en evidencia los trabajos de María Sierra y Juan Pro, que los modelos constitucionales de Inglaterra y Francia ocuparon un lugar de centralidad en las expectativas normativas de progresistas y moderados, respectivamente 23 , se aspira a demostrar que ambas tendencias siempre tuvieron un ojo puesto en el modelo estadounidense. A este respecto, el trabajo pretende

21 P. J. Marshall, Remaking the British Atlantic: The United States and the British Empire after American Independence, Oxford, Oxford University Press, 2012, pp. 192-220.

22 Eduardo Zimmermann, "Historia Global y Cultura Constitucional: Una nota sobre la traducción y circulación de doctrina juridica en la Argentina del siglo diecinueve”, Nuevo Mundo Mundos Nuevos, 2014, 1-13, https://doi.org/10.4000/nuevomundo.66772.

23 María Sierra Alonso, "El espejo inglés de la modernidad española: el modelo electoral británico y su influencia en el concepto de representación liberal", Historia y política: Ideas, procesos y movimientos sociales, $\mathrm{n}^{\circ}$ 21, 2009, pp. 139-167; Juan Pro, "El modelo francés en la construcción del estado español: el momento moderado", Revista de Estudios Políticos, n 175, 2017, pp. 299329, https://doi.org/10.18042/cepc/rep.175.10. 
ser un complemento a la importante reflexión de Florencia Peyrou, que ha demostrado cómo el constitucionalismo norteamericano se consolidó como el referente ideológico más importante de las corrientes republicanas escindidas del progresismo a partir de los 40. Peyrou demuestra que, tanto los republicanos liberales como los demosocialistas, pusieron a los Estados Unidos en el centro de sus argumentaciones en torno a la viabilidad de una revolución democratizadora y un sistema federal en España (si bien con claras omisiones e intervenciones interpretativas) ${ }^{24}$. El trabajo que aquí se ofrece lidia, por el contrario, con las lecturas más selectivas y matizadas que hicieron los exponentes del moderantismo y el progresismo, dispuestos como lo estuvieron a utilizar la experiencia constitucional angloamericana para cimentar sus respectivos ideales de Estado, sin renunciar a la forma politica de la Monarquía constitucional, y sin apostar por el sufragio universal o por un modelo territorial propiamente federal.

Se puede sugerir que moderados y progresistas se insertaron en un debate panatlántico en torno al constitucionalismo estadounidense, que vio colisionar, según interpreta Jonathan Israel, las visiones democráticas y revolucionarias legadas por la ilustración radical con los paradigmas más aristocráticos y monárquicos de la ilustración conservadora ${ }^{25}$. No obstante, la historia de la difusión transnacional del modelo estadounidense que compone Israel solo aborda -de forma poco convincente- la incidencia del modelo estadounidense en la Constitución de Cádiz y el republicanismo hispanoamericano, pasando por alto su influencia en el liberalismo postrevolucionario español ${ }^{26}$. Veremos que progresistas y moderados participaron del debate transnacional en torno al experimento democrático de los Estados Unidos, adhiriendo a este estratos ideológicos propios de la coyuntura temporal y geográfica en la que reflexionaban, e introduciendo así un tamiz hispanista, historicista y nacionalista en sus interpretaciones.

A efecto de llevar a buen término el análisis propuesto, el artículo relaciona las herramientas heurísticas de los estudios basados en dos categorías intimamente relacionadas: cultura politica y cultura constitucional. Se entiende el concepto de cultura politica, en línea con los estudios historiográficos a este respecto, como el conjunto de experiencias, relatos, expectativas, y modelos ideales de sociedad que condicionan las conductas públicas, las identificaciones grupales y las pautas de acción colectiva de los actores sociales que interactúan en el seno de un sistema político determinado ${ }^{27}$. Por cultura constitucional, siguiendo la definición sugerida por Juan Luis Simal, se haría referencia a las matrices de significado (simbólicas, teóricas y narrativas) que condicionan la elaboración doctrinal de un texto constitucional, así como su formulación, su

24 Florencia Peyrou, "Los republicanos españoles y los otros. Impacto e influencia de los modelos republicanos foráneos, 1840-1874," Revista de Estudios Políticos, n ${ }^{\circ}$ 175, 2017, pp. 341347. https://doi.org/10.18042/cepc/rep.175.11.

25 Israel, The Expanding Blaze How the American Revolution Ignited the World, 1775-1848, , op. cit., pp. 16-17.

26 Israel, The Expanding Blaze How the American Revolution Ignited the World, 1775-1848, , op. cit., pp. 423-455.

27 Miguel Ángel Cabrera, "La investigación histórica y el concepto de cultura politica”, en Manuel Pérez Ledesma y María Sierra (edit.), Culturas politicas: teoría e historia, Institución Fernando el Católico, Zaragoza, 2010, pp. 78-80. 
interpretación y su desarrollo ${ }^{28}$. Dichas categorías implicarian también una determinada cultura de la legalidad, es decir, una mentalidad específica en torno a la naturaleza de las instituciones, la normatividad jurídica y las fuentes y los fines del derecho ${ }^{29}$. Sería posible afirmar que las culturas politicas del progresismo y el moderantismo español ${ }^{30}$ funcionaron como los entramados de relatos, valores y expectativas que determinaron la cultura constitucional de ambas corrientes y sus estrategias de interpretación y representación del modelo político-jurídico estadounidense.

Este enfoque metodológico permite estudiar el pensamiento constitucional de progresistas y moderados como una historia de las disputas semánticas en torno a los conceptos fundamentales que se asociaban al modelo angloamericano y que se aspiraba fuesen decisivas en el sistema normativo y politico de la Monarquía: representación, soberanía popular, democracia y federación, entre otras ${ }^{31}$. El estudio así propuesto se alinea con lo que Joaquín Varela ha llamado la "perspectiva doctrinal" de la historia constitucional, es decir, el abordaje de las reflexiones intelectuales que le dieron forma a la arquitectura institucional y política del Estado liberal $^{32}$. En este caso, dichas reflexiones estuvieron mediadas por las representaciones culturales de la república angloamericana y por el contexto de disputa politica interna en que fueron enunciadas. Los moderados y los progresistas se consolidaron, asi, como genuinas "tendencias constitucionales"33 que incorporaron visiones competitivas del modelo estadounidense, dándole lecturas ideologizadas a las fuentes doctrinales que este ofrecía.

A efectos de estudiar el fenómeno descrito, el artículo centrará su atención en una gama variada de fuentes ${ }^{34}$. En el centro se situarán los discursos jurídicos, historiográficos y ensayísticos de los pensadores más relevantes de cada tendencia ideológica abordada. Estas fuentes, que incluirán obras escritas,

28 Juan Luis Simal, "Circulación Internacional de Modelos Politicos En La Era Postnapoleónica: Cultura, Debate y Emulación Constitucionales", Revista de Estudios Políticos, n 175, 2017, pp. 272-273, https://doi.org/10.18042/cepc/rep.175.09.

29 José María Sauca Cano, "Cultura de la Legalidad. Bosquejo de exploraciones conceptuales y metodológicas”, Asamblea: revista parlamentaria de la Asamblea de Madrid, n 22, 2010, pp. 2426.

30 En puridad, se podrian catalogar al progresismo y al moderantismo como subculturas politicas, pero a efectos de simplificar el planteamiento, se mantiene su nomenclatura habitual como culturas politicas: Autor, 2021, 6-7.

31 Elias José Palti, "The 'Theoretical Revolution' in Intellectual History: From the History of Political Ideas to the History of Political Languages", History and Theory, $\mathrm{n}^{\circ}$ 53, 2014, pp. 387-405, https://doi.org/10.1111/hith.10719; Saul Cornell, "Constitutional Meaning and Semantic Instability: Federalists and Anti-Federalists on the Nature of Constitutional Language", American Journal of Legal History, $\mathrm{n}^{\circ}$ 56, 2016, pp. 21-28, https://doi.org/10.1093/ajlh/njv025.

32 Joaquín Varela Suanzes-Carpegna, "Algunas reflexiones metodológicas sobre la Historia Constitucional” Historia Constitucional: Revista Electrónica de Historia Constitucional, n 8, 2007, p. 247. https://doi.org/10.17811/hc.v0i8.39

33 Joaquín Varela Suanzes-Carpegna, “Algunas reflexiones metodológicas sobre la Historia Constitucional", op. cit., pp. 252-253.

34 El propio Varela-Suanzes hace notar el carácter poliédrico de las fuentes de información empleables para analizar el pensamiento constitucional de una sociedad: Joaquín Varela Suanzes-Carpegna, "Algunas reflexiones metodológicas sobre la Historia Constitucional", op. cit., p. 247 . 
lecciones académicas e intervenciones parlamentarias, se complementarán con el estudio de los periódicos más relevantes de cada corriente. También se abordarán las ediciones y traducciones de los textos jurídicos estadounidenses, así como de los autores angloamericanos y europeos que los habian descrito. En este sentido, no se renunciará a analizar los "paratextos"35, es decir, la amplia gama de prólogos, reseñas y acotaciones con que los traductores, editores y comentaristas del liberalismo español emitieron su interpretación sobre las propias obras que ellos lanzaban al mercado editorial.

En un primer apartado se analizarán las representaciones del constitucionalismo estadounidense realizadas por los liberales progresistas, sin dejar de mencionar su contraste con los pensadores republicanos y demosocialistas -como Pedro Méndez de Vigo, Ramón de la Sagra y Fernando Garrido-. A tal efecto, se centrará en textos como el estudio monográfico en torno a la democracia estadounidense publicado por el diputado Miguel Cabrera de Nevares. Este se complementará con las traducciones, reseñas y ediciones realizadas por los publicistas Ángel Iznardi y Gabino Gasco; y con los discursos parlamentarios y los escritos de lideres como Agustín Argüelles, José Manuel Vadillo, Domingo María Vila, Dionisio Valdés, Ángel González, Manuel Torrijos y Miguel Alejos Burriel. Sus obras e intervenciones se acompañarán con el estudio de la producción de periódicos ideológicamente afines al progresismo: principalmente El Eco del Comercio, El Guardia Nacional y El Constitucional.

En un segundo apartado, se abordarán los imaginarios transatlánticos del moderantismo, ofreciendo a su vez comentarios respecto de sus trasvases con ciertos pensadores antiliberales - en este caso, Mariano Torrente y George Dawson Flinter-. Para ello se abordarán las obras e intervenciones docentes de algunos de los principales líderes político-intelectuales del Partido Moderado: Francisco Martínez de la Rosa, Antonio Alcalá Galiano, el Conde de Toreno; y los más conservadores Fermín Gonzalo Morón, José María Aurrecoechea y José María Rivero. También se abordará la prensa cercana al moderantismo, principalmente El Castellano, El Heraldo y El Español.

En base a estas fuentes, el artículo pretende contribuir a la historiografia transnacional sobre el impacto global del constitucionalismo americano. A este respecto, se aspira a ofrecer un complemento al ya clásico estudio de David Armitage en torno a la influencia de la Declaración de Independencia a la hora de consagrar el principio de autodeterminación nacional como núcleo del derecho internacional en el mundo contemporáneo ${ }^{36}$. Asimismo, el artículo puede contribuir a continuar la reflexión de trabajos como el antes mencionado de Jonathan Israel, y otros como los de Eduardo Zimmermann ${ }^{37}$, Colin Crawford, Daniel Maldonado ${ }^{38}$, Alexander $\mathrm{Cruz}^{39}$ y George Billias ${ }^{40}$, que han estudiado de

35 Zimmermann, "Historia Global y Cultura Constitucional”, op. cit., p. 7.

36 David Armitage, Foundations of Modern International Thought, Cambridge University Press, Cambridge, 2013, pp. 191-214

37 Eduardo Zimmermann, 'Translations of the "American Model" in Nineteenth Century Argentina: Constitutional Culture as a Global Legal Entanglement' in Thomas Duve (Edit.), Entanglements in Legal History: Conceptual Aproaches, Max Planck Institute for European Legal History, 2014, pp. 385-421.

38 Colin Crawford and Daniel Bonilla Maldonado (edits.), Constitutionalism in the Americas, Edward Elgar, Northhampton MA, 2018. 
forma notable las estrategias de apropiación y adaptación local del sistema constitucional de los Estados Unidos en Europa y América Latina. Significativamente, estas reflexiones, que han ayudado a situar la historia constitucional de la Unión norteamericana en el contexto transnacional que le corresponde, han dejado inexplorada su influencia en la cultura constitucional del imperio español. Esta falta de atención puede estar relacionada con una carencia interpretativa detectada por Hilda Sábato. La historiadora argentina subraya que las experiencias politicas de España y las repúblicas hispanoamericanas durante el siglo XIX continúan siendo "marginales a las narrativas hegemónicas sobre la modernidad política"41.

Afortunadamente, algunos estudios, como los de Kate Ferris ${ }^{42}$, Wayne Bowen ${ }^{43}$, Alessandro Seregni ${ }^{44}$, David Corrales Morales ${ }^{45}$ y Daniel Fernández de Miguel $^{46}$ han comenzado a estudiar la importancia de las imágenes de Estados Unidos en la historia del pensamiento político y constitucional de la España contemporánea, si bien centrándose principalmente en una cronología que aborda la Revolución Gloriosa de 1868, el Desastre del 98 y el Siglo XX. Sin embargo, poco se ha estudiado aún cómo las representaciones de la democracia estadounidense incidieron en el pensamiento constitucional de las culturas políticas españolas durante los años de formación del Estado liberal, ni cómo estas construyeron visiones heterogéneas y enfrentadas del sistema políticojurídico de la república. Tampoco se ha explicado cómo las relaciones postimperiales de las potencias del Atlántico anglosajón influyeron en las estrategias de interlocución diplomática que la Monarquía española sostuvo hacia sus antiguas dependencias hispanoamericanas ${ }^{47}$. El artículo se postula para contribuir en estos frentes, nivelando el conocimiento sobre el tema con otros campos relacionados que han gozado un notable desarrollo, como los análisis en

39 Alexander Cruz Martinez, "La idea de federalismo en las constituciones nacionales de Argentina y Colombia durante la primera mitad del siglo XIX", Historia constitucional: Revista Electrónica de Historia Constitucional, $n^{\circ} 16,2015$, pp. 389-406.

40 George Billias, American Constitutionalism Heard Round the World, 1776-1989: A Global Perspective, NYU Press, Ney York, 2009.

41 Hilda Sábato, Republics of the New World: The Revolutionary Political Experiment in Nineteenth-Century Latin America, Princeton University Press, Princeton, 2018, p. 1

42 Kate Ferris, Imagining "America" in Late Nineteenth Century Spain, Palgrave MacMillan, Basingstoke, 2016.

43 Wayne H Bowen, Spain and the American Civil War, University of Missouri Press, Columbia, 2011.

44 Alessandro Seregni, El antiamericanismo español, Editorial Sintesis, Madrid, 2007.

45 David Corrales Morales, "Reflejos del futuro presente. Imágenes de los Estados Unidos en la prensa española de principios del Siglo XX (1898-1914)", Revista de Indias, n 270, 2017, pp. 551583, https://doi.org/10.3989/revindias.2017.018.

46 Daniel Fernández de Miguel, El Enemigo Yanqui: las raíces conservadoras del antiamericanismo español, Genueve, Zaragoza, 2012.

47 Hay algunos trabajos recientes que tocan este tema: Autor, 2019c, pp. 265-293. 
torno al legado jurídico del imperio español en los Estados Unidos ${ }^{48}$; o las visiones del mundo hispánico que se dieron en la cultura angloamericana ${ }^{49}$.

\section{ESCUELA DE LIBERTAD. EL MODELO ESTADOUNIDENSE EN EL PENSAMIENTO PROGRESISTA}

\subsection{Constitucionalismo de imprenta y movilización exaltada: traducción, edición y exégesis politizada.}

A fin de entender los usos politicos que las culturas constitucionales del liberalismo postrevolucionario les dieron a sus representaciones de la democracia norteamericana es necesario rastrear los canales concretos por los cuales circuló información en torno al modelo constitucional estadounidense. A este respecto, es posible detectar un ciclo de traducción y edición de fuentes referentes al sistema institucional norteamericano durante la segunda mitad de los años 30, coincidiendo particularmente con las movilizaciones organizadas por los progresistas contra el régimen del Estatuto Real de 1834. El carácter marcadamente conservador y monárquico del Estatuto estaba lejos de las expectativas de los liberales doceañistas o exaltados. Estos comenzaron a movilizar a juntas y milicias revolucionarias en los núcleos urbanos con el fin de reclamar una sustantiva expansión del principio de soberanía popular, del derecho de sufragio y del poder parlamentario. Finalmente, el 12 de agosto de 1836, el "motín" de la Granja logró descartar el odiado Estatuto y forzó a la regente Maria Cristina a proclamar la restitución de la Constitución de $1812^{50}$.

En este contexto, los círculos intelectuales y editoriales del arco progresista protagonizaron el acopio y la traducción de fuentes legales e historiográficas que permitieron conocer las bases y el funcionamiento del constitucionalismo norteamericano. Es sintomático que fuera la imprenta de El Eco del Comercio, el gran diario progresista de la coyuntura, la encargada en distribuir una versión en español de la Constitución estadounidense de 1787 y de las 10 enmiendas que componían la Declaración de Derechos de 179151. Esto sucedió en 1836, es decir, el año en que el Partido Progresista orquestó las movilizaciones que llevaron a la caida de los gabinetes moderados que amparaban el orden del Estatuto Real, impulsando así la restitución de la Pepa en agosto y a la convocatoria de Cortes Constituyentes.

\footnotetext{
48 Peter L. Reich, "Dismantling the Pueblo: Hispanic Municipal Land Rights in California Since 1850", American Journal of Legal History, n45, 2001), pp. 353-370, https://doi.org/10.2307/3185311.

49 Ivan Jaksic, Ven conmigo a la España lejana: los intelectuales norteamericanos ante el mundo hispano: 1820-1880, Fondo de Cultura Económica, Santiago, 2007; Andrés Sánchez Padilla, "Entre la modernidad y el absolutismo: la percepción de España en la diplomacia norteamericana (1868-1898)", Historia y política: Ideas, procesos y movimientos sociales, $\mathrm{n}^{\circ} 36,2016$, pp. 163190.

50 Joaquín Varela Suanzes-Carpegna, La monarquía doceañista (1810-1837): avatares, encomios y denuestos de una extraña forma de gobierno, op. cit., pp. 385-91.

51 Ángel Iznardi, Colección de Constituciones, en la que van puestas en castellano las de Francia, Bélgica, Portugal, Brasil y Estados-Unidos Anglo-Americanos, con la española de 1812 y su discurso preliminar, $2^{\mathrm{a}}$ ed, Imprenta del Eco del Comercio, Madrid, 1836.
} 
La mencionada edición de la Constitución angloamericana fue ejecutada, precisamente, por el fundador de El Eco del Comercio, Ángel Iznardi52. Diputado por Huelva y por Cádiz con los progresistas entre 1836 y 1841, Iznardi era un periodista y publicista que había combatido al régimen absolutista, pasando periodos de encarcelamiento y de exilio en París y vinculándose mediante las logias masónicas con algunos de los principales líderes politicos del progresismo, como Juan Álvarez Mendizábal y José María Calatrava53. Fue él quien firmó esta edición de la constitución estadounidense, la cual se publicó en una Colección que incluía, además, los textos constitucionales de las monarquías de Francia (1830), Bélgica (1831), Portugal (1826), y el Imperio del Brasil (1824), junto a la Constitución española de 1812. Significativamente, el editor seleccionó las cartas de cuatro monarquías constitucionales nacidas durante el último ciclo de las revoluciones liberales ibéroamericanas y de la Europa continental euroamericanas (Portugal, Brasil, Francia y Bélgica), para colocarlas junto a la Constitución española de 1812. Esta última se había convertido, a la altura de 1836, en el referente simbólico de los reformadores progresistas que, sin embargo, estaban convencidos de la necesidad de adaptar pragmáticamente el texto a los equilibrios de poder de los años $30^{54}$.

Es por ello, probablemente, que la Colección incorporase constituciones que, si bien ofrecian modelos múltiples de ciudadanía y territorialidad, eran asociadas a proyectos estables de monarquismo parlamentario. La inclusión de la constitución estadounidense como el único texto republicano, con la notable omisión de la Constitución francesa de 1793, implicaba concebir a la federación angloamericana como un ejemplo viable, estable y respetable de arquitectura politico-jurídica. Se colegía que, a la altura de 1836, esta había demostrado su durabilidad, logrando trascender los utopismos del contractualismo radical que había presidido las revoluciones de finales del siglo XVIII.

En el prólogo a la colección, Iznardi declaraba que esta se realizaba con el fin de orientar a los diputados progresistas en la redacción de un nuevo texto constitucional que pudiese reflejar "las luces del siglo": "Ahora que España va á constituirse, no solo es útil, sino hasta necesario, que se generalicen y conozcan en lengua vulgar las principales constituciones porque se gobiernan estados grandes y adelantados en la civilización" 55 . A este respecto, Iznardi defendía que la "Constitución Angloamericana" era un componente esencial en el acervo jurídico del liberalismo euroamericano. Asumiendo que el constitucionalismo era la expresión de un proceso teleológico de emancipación social, moral y económica de las sociedades civiles respecto de las jerarquías monárquicas y eclesiásticas ${ }^{56}$,

52 Iznardi había delegado la dirección del periódico a los también progresistas Fermín Caballero y Manuel Francisco Mendialdua: Daniel Aquillué Domínguez, "La forja de una cultura politica: el incipiente progresismo a través de las páginas del Eco del Comercio. 1834-1837" en Antonio Caballero Machí (Edit.), Culturas politicas en la contemporaneidad: Discursos y prácticas politicas desde los márgenes a las élites, Universitat de València, Valencia, 2015, pp. 53-57.

53 Futuros ministros y hombres fuertes en los gabinetes progresistas.

54 Antoni Moliner i Prada, "El mito de 'la Pepa': (1812-1912)," in Història local recorreguts pel Liberalisme i el Carlisme: homenatge al doctor Pere Anguera (Barcelona: Editorial Afers, 2012), 39094.

55 Ángel Iznardi, Colección de Constituciones, op. cit., p.9.

${ }^{56}$ Esta visión teleológica y triunfalista de la era de las Revoluciónes fue visible en los trabajos historiográficos de varios colaboradores y futuros integrantes del progresismo, como Adolfo de 
el fundador de El Eco presentaba la labor de las Cortes constituyentes que se reunian en ese momento en España como una continuación de la empresa civilizatoria abierta por los legisladores estadounidenses. Asi, el "paratexto" que acompañaba a aquella traducción y edición de la Constitución de 1783 y de la Declaración de Derechos de 1791 tenía ciertamente la vocación instrumental de servir como fuente doctrinal. Según el propio Iznardi, su Colección permitiría acceder con facilidad al corpus de conocimientos que contenía el articulado de los textos estadounidenses de cara a adaptarlos parcialmente al contexto constituyente español ${ }^{57}$.

Al mismo tiempo, la edición tenía también un marcado carácter propagandístico y legitimador: su difusión pretendía encuadrar la ascendencia del Partido Progresista y la redacción de la Constitución de 1837 como parte del contexto de un aparente triunfo transatlántico del parlamentarismo liberal. A tal efecto, relacionar el proyecto político de signo reformista y descentralizador de los progresistas con la constitución de una república federal representada como próspera, grande y estable, permitía desmentir las acusaciones de radicalismo y utopismo a las que eran sometidos los progresistas por parte de los sectores moderados. La Colección de Iznardi vinculaba en una sola unidad de sentido el constitucionalismo estadounidense, el ibérico y el europeo, para homologar la tradición del liberalismo español con sus homólogas euroamericanas, presentando implícitamente al doceañismo como el legítimo exponente de la modernidad política en España ${ }^{58}$. No es casual que, solo en su primer año de publicación (1836), la Colección alcanzase dos ediciones, anunciada como lo fue entre los actores que componian el entramado de juntas, milicias y escaños del progresismo.

Como se demostrará, la Constitución de 1783 y la Declaración de Derechos fueron los textos más comentados por los exaltados. Estos tuvieron acceso a ellos gracias a iniciativas como la de Iznardi y a traducciones anteriores que se habian realizado en el marco de las Cortes de Cádiz (1810-1812), cuando los liberales habian tenido una necesidad análoga de legitimación y comparación

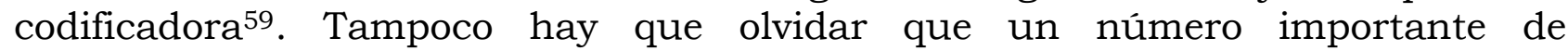
progresistas que vivieron el exilio en Londres tuvieron la oportunidad de consultar las reproducciones de estos documentos que ofrecía periódicamente el mercado editorial inglés. Algunos de los grandes intérpretes del constitucionalismo americano en el seno del liberalismo radical español, como Pedro Méndez de Vigo ${ }^{60}$ y José María Blanco White ${ }^{61}$, tuvieron ocasión de acceder

Castro y Rossi, Exámen filosófico sobre las principales causas de la decadencia de España, Imprenta de D. Francisco Pantoja, Cádiz, 1852.

57 Ángel Iznardi, Colección de Constituciones, op. cit., pp. 101-24.

58 Ángel Iznardi, Colección de Constituciones, op. cit., pp. 10-11.

59 Anónimo, Constitución de los Estados-Unidos de América: formada por una convención de los Estados, que se inició en sesion de 25 de mayo, y terminó en 17 de septiempre de 1787. Imp. de D. Manuel Ximenez Carreño, Cádiz, 1811.

60 Pedro Méndez de Vigo, España y América en progreso, Imprenta de H. Fournier, París 1835, p. 40. El republicano Pedro Méndez de Vigo obtendría información respecto al sistema político de Estados Unidos a partir del libro de viajes redactado por el jurista Lorenzo de Zavala, un importante líder de la independencia mexicana que admiraba sin ambages el sistema del vecino del Norte, hasta el punto de participar activamente de la secesión y fundación de la República de Texas: Lorenzo de Zavala, Viage a Los Estados-Unidos del Norte de América, Imprenta de Decourchant, Paris, 1834. 
a varias obras historiográficas y relatos de viajes en que los Whigs y radicales británicos y los republicanos hispanoamericanos construían una imagen benéfica de las leyes americanas. En cualquier caso, los exiliados estuvieron siempre predispuestos a emplear estos diálogos intertextuales con el constitucionalismo estadounidense en clave de politica doméstica.

Por otro lado, la Declaración de Independencia también fue comentada y parcialmente reproducida ${ }^{62}$. Sin embargo, su uso a lo largo de las décadas siguientes se restringió a evocaciones románticas y puntuales por parte de los actores republicanos y a contextos de conflictividad en que se precisaban arengas en clave democrática e igualitaria63. De nuevo, fueron más frecuentes los usos retóricos que los análisis pormenorizados de sus dictados normativos. Otros textos fundamentales, como los Federalist Papers o los trabajos de Jefferson tuvieron una difusión reducida y no aparecieron con asiduidad en el discurso público.

Mucho más relevantes fueron las traducciones de las obras americanistas de ciertos viajeros e historiadores europeos e hispanoamericanos. Las editoriales, percibiendo el interés político existente por la historia institucional de la federación anglosajona, lanzaron al mercado varios libros que facilitaban una lectura en clave apologética del constitucionalismo estadounidense. Entre estas traducciones destacaron algunas como la de la Historia de los Estados Unidos escrita por Roux La Rochelle ${ }^{64}$; o la descripción laudatoria del republicanismo estadounidense publicada en francés en 1832 por Achille Murat, el cuñado de Napoleón emigrado a Florida ${ }^{65}$. El traductor de la segunda, aparecida en Madrid en 1836, fue el futuro diputado del Partido Progresista por Logroño, el abogado y publicista Gabino Gasco ${ }^{66}$. En el prólogo de la obra, Gasco recurría al relato canónico de la historia universal y americana al que apelaban habitualmente los representantes euroamericanos del liberalismo radical, asociándola, en la línea de Thiers, con la lucha dialéctica entre los pueblos y las élites estamentales y eclesiásticas $^{67}$. Según él, los Estados Unidos eran la vanguardia de un proceso

61 José Maria Blanco White, The Life of the Rev. Joseph Blanco White, Written by Himself; with Portions of His Correspondence., vol. III, John Chapman, London, 1845, pp. 296-98. Blanco White citaría con asiduidad los trabajos de viajeros ingleses de militancias radicales, como el trabajo filodemocrático del abolicionista Edward Strutt Abdy Edward Strutt Abdy, Journal of a Residence and Tour in the United States of North America: From April, 1833, to October, 1834, Murray, London, 1835.

62 E.g. "Noticias Estrangeras", El Eco del Comercio, 21 de octubre de 1838.

63 E.g. Fernando Garrido, La humanidad y sus progresos o la civilización antigua y moderna. Tomo I, Salvador Manero, Barcelona, 1867, p. 364.

64 Una obra de varios tomos en la que el embajador francés en Estados Unidos ofrecía una visión positiva de la federación: Roux de Rochelle, Historia de los Estados-Unidos de América, Imp. del Guardia Nacional, Barcelona, 1841.

65 Achille Murat, Esquisse morale et politique des Etas-Unis de l'Amerique du Nord, Crochard, París, 1832, http://archive.org/details / esquissemoraleet00mura.

66 Gabino Gasco, "Prólogo", en Achille Murat, Esplicación de los principios del gobierno republicano, del cual ha sido perfeccionado en los Estados Unidos de América, (Imprenta de Don Marcelino Calero, Madrid, 1836.

67 Stefan Berger, "The Invention of European National Traditions in European Romanticism", in Stuart Macintyre, Juan Maiguashca, and Attila Pók, The Oxford History of Historical Writting. Volume 4: 1800-1945, Oxford University Press, Oxford; New York, 2011, pp. 19-40. 
revolucionario que estaba conduciendo a los regímenes monárquicos, corporativos y confesionales del Antiguo Régimen a dejar paso a la formación de sociedades nacionales igualitarias y de sistemas de gobierno regidos por la voluntad de la mayoria68. Su evocación en clave filo-revolucionaria de la federación anglosajona iba debidamente acompañada de una insistencia taxativa en el hecho de que su experimento democrático ${ }^{69}$ era consustancial a la prosperidad económica, a la paz social, al respeto a la propiedad y, sobre todo, a una armonía irreductible entre los intereses de la sociedad, las leyes y la acción de gobierno:

\begin{abstract}
"En medio de la agitación de las naciones por llegar al objeto que buscan, en medio de la lucha de los pueblos contra los reyes, y de los reyes contra los pueblos, vemos los Estados-Unidos de la América del Norte marchan por el carril de la civilización con una celeridad qué no tiene ejemplo en la historia. ¡Qué espectáculo tan magnífico nos presentan! Toda disputa se defiende y termina alli amigablemente, siendo la mayoría juez supremo de lás contiendas de las minorías. En ningún caso tiene lugar la fuerza brutal. Reina un sumo respeto á las leyes. (...) En los Estados-Unidos de la América del Norte hay 13.000,000 de hombres libres que gozan de un estado de prosperidad, sin ejemplo en la historia.; no como se dice, porque están diseminados sobre un inmenso territorio, ó porque se hallan lejos de Europa; sino porqué son libres y están bien gobernados; porque jamás ni en parte alguna han estado tan seguras la vida y la propiedad; porque las leyes son hechas en interés de todos, y no de una clase privilegiada i porque reina la igualdad"70.
\end{abstract}

Gasco, a través de este prólogo a Murat, trataba de desmentir con esta representación la vinculación entre el constitucionalismo democrático, el desorden público y la anomia legal que acostumbraban a urdir los intelectuales moderados y los absolutistas españoles ${ }^{71}$. Con ello, deseaba asociar explícitamente su descripción utópica de la democracia con el proyecto político de los progresistas, que en el momento en que la traducción fue publicada (los últimos meses de 1836) estaban volcados en la redacción de una constitución que sancionase su hegemonía cultural y politica. El futuro diputado, que tachaba su traducción de "servicio a la patria", declaraba abiertamente esta intención legitimadora e inspiracional:

"Este servicio és tanto mas interesante, cuanto siendo aplicable la mayor parte de los mismos [los principios constitucionales de los Estados Unidos] á toda

68 Gabino Gasco, "Prólogo", en Achille Murat, Esplicación de los principios del gobierno republicano, del cual ha sido perfeccionado en los Estados Unidos de América, op.cit., pp. 2-4.

69 Los escritores españoles utilizaron mucho el término de "experimento" para referirse a la estructura constitucional de los Estados Unidos, utilizando así un término muy empleado por los propios constitucionalistas norteamericanos: Marcos Reguera, "El "experimento americano" y los orígenes del concepto moderno de revolución”, Revista de Estudios Políticos, n 182, 2018, pp. 7198, https://doi.org/10.18042/cepc/rep.182.03.

70 Gabino Gasco, "Prólogo", en Achille Murat, Esplicación de los principios del gobierno republicano, del cual ha sido perfeccionado en los Estados Unidos de América, op.cit., pp. 5-6.

71 Francisco de Gregorio, Marqués de Valle Santoro, Examen filosófico de la Revolución Americana, Imprenta de Verges, Madrid, 1832. 
clase de gobierno, y tratándose, corno se trata, de reformar la constitución española, podría echarse mano de alguno ó algunos de ellos con suma utilidad, y salir así de las manos de los representantes, si no una constitucion acabada, al menos que se aproximase a la perfección"72.

Gasco presentaba así la obra de Murat como un verdadero instrumento de combate político. La idea de fondo era que una descripción positiva de las instituciones y leyes fundamentales de la federación norteamericana podía servir como artilleria doctrinal a los progresistas en sus violentas disputas parlamentarias con el arco conservador. También como "experiencia" susceptible de estimular la prudencia de los legisladores exaltados en la redacción de la Constitución de 1837.

La alabanza de las leyes de Estados Unidos cobraba el carácter de mito orientativo por intermediación de las representaciones filo-democráticas de Murat, que a su vez eran alteradas por la intervención editorial de Gasco $^{73}$. Varios estratos de significación subjetiva se interponian entre el contenido efectivo de los textos legales americanos y los lectores de la traducción. Finalmente, la imagen del constitucionalismo norteamericano se convertía en un artefacto discursivo que servía para apoyar el asalto al poder de los progresistas, indisociable de la aprobación de una constitución que debía consagrar la ampliación del sufragio, el poder parlamentario y el principio de soberanía popular frente a las prerrogativas de la Corona ${ }^{74}$. No es casual que la editorial que promocionó la traducción de Gasco fuese la que regentaba Marcelino Calero, que había retornado a España para convertirse en todo un promotor de la causa de los exaltados.

La estrecha vinculación entre las movilizaciones progresistas, la representación celebratoria del sistema constitucional estadounidense y la emergencia de un mercado lector para las traducciones en torno a la república ultramarina continuó haciéndose evidente a lo largo de la década siguiente ${ }^{75}$. El mejor ejemplo de esta dinámica de "constitucionalismo de imprenta" fue el éxito de la obra La Democracia en América, de Alexis de Tocqueville ${ }^{76}$, cuyas ediciones francesas penetraron relativamente pronto en España. Sin embargo, su popularización entre las élites intelectuales de la Monarquía sucedió al compás de

72 Gabino Gasco, "Prólogo", en Achille Murat, Esplicación de los principios del gobierno republicano, del cual ha sido perfeccionado en los Estados Unidos de América, op.cit., p. 8.

73 Sobre las dinámicas ideologizadas de intervención editorial en la España liberal: Rodrigo Escribano Roca, "Ediciones Imperiales: la Colección de documentos inéditos relativos a las posesiones españolas en América y Oceanía y la construcción de un pasado panhispánico (18641936)", Journal of Spanish Cultural Studies 20, $\mathrm{n}^{\circ}$ 4, 2019, pp. 381-401, https://doi.org/10.1080/14636204.2019.1689683.

74 Daniel Aquillué Domínguez, “La Constitución de 1837: ¿una Constitución transaccional?”, Revista Historia Autónoma, n 6, 2015, pp. 45-59.

75 Por ejemplo, el establecimiento editorial dirigido por el progresista Pascual Madoz perpetuó su interés americanista con nuevas traducciones de todo signo politico: François-René Chateaubriand, Viaje a América, Est. Literario-Tipográfico de P. Madoz y L. Sagasti, Madrid, 1846.

76 Alexis de Tocqueville, De la Démocratie en Amérique, Librairie de Charles Gosselin, Paris, 1835. 
su traducción en $1843^{77}$. La segunda edición de la versión en español de la obra de Tocqueville en 1854 demostró, por cierto, cómo el ala demo-republicana que se escindió del progresismo en 1849 para fundar el Partido Democrático, continuó con las prácticas de edición y divulgación de textos referentes al sistema político norteamericano. Esta fue ejecutada por uno de los lideres del Partido Demócrata, el gallego Eduardo Chao. Este polígrafo republicano, que llegaría a ser Ministro de Fomento en la I Republica Española (1873), mantendría, como se ha dicho, la tradición de vincular la edición de fuentes en torno al constitucionalismo americano con la agenda politica del liberalismo radical español, ahora en un contexto de oposición a la hegemonía conservadora de los años 40 y 50.

Sin embargo, el contenido de la obra de Tocqueville no llegó al público solo a través de la lectura directa, sino también mediante las reseñas de la misma publicadas en la prensa. Si los autores conservadores, como Fermín Gonzalo Morón, emplearon las reseñas de la obra tocqueviliana para representar la arquitectura constitucional americana como un campo que abonaba la demagogia, la violencia social y el desorden jurídico ${ }^{78}$, los reseñistas progresistas se aplicaron a la tarea contraria. Eliminando los elementos críticos e irónicos que abundaban en la obra del francés, emplearon su discurso para presentar a la legislación americana con tintes claramente apologéticos. Entre los reseñistas de Tocqueville más empeñados en la reivindicación de las bondades del modelo estadounidense estuvo el mencionado Ángel Iznardi. En 1846, tras haber dejado la dirección de El Eco del Comercio, escribió en El Clamor Público ${ }^{79}$, empleando el comentario del trabajo de Tocqueville para desarrollar un análisis de tono vindicativo sobre las lecciones arrojadas al mundo occidental por el experimento politico-territorial de los norteamericanos ${ }^{80}$.

De estas descripciones se desprende que la intelligentsia progresista, apoyándose en su formación políglota, protagonizó, a partir de la segunda mitad de los años 30, un verdadero proceso de captación y socialización de información primaria y secundaria en torno al sistema constitucional de los Estados Unidos. Como se ha podido apreciar, incluso este proceso recopilatorio y editorial, aparentemente aséptico, estuvo vehiculado por objetivos políticos y simbólicos muy concretos. La recopilación, traducción y edición de la Constitución de 1783 y la Declaración de Derechos de 1791 no respondió tanto a una búsqueda científica de fuentes jurídicas, como a la necesidad de construir una mitología en torno a la democracia estadounidense con fines legitimadores, propagandísticos y orientativos. En este sentido, los documentos legales y los trabajos secundarios consultados (Tocqueville, Murat, etc) fueron tratados como una unidad, en que las especificidades y complejidades juridicas de cada texto cedian el paso a la necesidad que progresistas españoles tuvieron de construir un relato coherente.

77 Alexis de Tocqueville, De la Democracia en América, Imprenta de Don Nicasio Sánchez, Madrid, 1843.

78 Fermin Gonzalo Morón, "Gobierno y costumbres de los Estados Unidos. Reseña y juicio de la obra 'De la Democracia en América por Ms. Alexis de Tocqueville'. Examen de los bienes y males de la democracia. Articulo 2o", Revista de España y del Estrangero, n I, 1842, pp. 71-91.

79 Diario fundado por Fernando Corradi en 1844 que representó al ala radical del progresismo.

80 Ángel Iznardi, "Gobierno y costumbres de los Estados-Unidos. Análisis de La obra de M. Tocqueville, titulada, De la Democratie en Amerique", El Clamor Público. Periódico liberal. 29 de julio de 1846, pp. 3-4. 
Las bases para la mitologización del constitucionalismo americano estaban puestas.

\subsection{Internacionalismo postimperial y municipalismo: la inspiración norteamericana}

La presencia del modelo estadounidense en la cultura constitucional del progresismo se vio también cimentada por la experiencia personal y directa de algunos actores. Fue el caso de Miguel Cabrera de Nevares. Este militar y escritor habia sido uno de los principales defensores de la Constitución de 1812 y le había prestado servicios al Ministerio de Ultramar de los gobiernos constitucionales del Trienio Liberal (1820-1823), ejerciendo también como jefe político de la provincia de Calatayud en el mismo periodo. Su decidida defensa de la abolición de los privilegios jurisdiccionales del Antiguo Régimen, y su apoyo a esquemas de descentralización y liberalización en los virreinatos de ultramar, supusieron su persecución por parte de los absolutistas. Esto le valió dos destierros a las Américas. El segundo de ellos, ya en 1823, le llevó a los Estados Unidos, donde acudió atraído por las promesas de lucro comercial y por la posibilidad de contemplar directamente el funcionamiento de su modelo constitucional ${ }^{81}$. El expatriado se integró rápidamente en los círculos de exiliados y activistas hispanoamericanos que prosperaban en Nueva York. En estos hizo amistad con pensadores constitucionales adeptos al republicanismo liberal, como el peruano Manuel Lorenzo de Vidaurre. Sus amistades le permitieron ganar en 1832 una professorship de literatura en la Universidad de Columbia ${ }^{82}$.

Desde esta atalaya privilegiada, Cabrera había contemplado la expansión migratoria más allá de Missouri, Colorado y Texas, la deriva democrática de la república con la elección del presidente Jackson y el crecimiento sin precedentes de los mercados exportadores de las ciudades del este americano ${ }^{83}$. En este contexto, había preparado una serie de Observaciones. Tras la apertura de la monarquía isabelina al constitucionalismo, habia sido reclamado por sus amigos politicos para volver a España e integrarse en las filas del Partido Progresista. Siendo ya gobernador civil de Toledo en 1835, le entregó al Secretario de Estado Diego Medrano unas Memorias que pretendian describir las características político-económicas más relevantes de los Estados Unidos ${ }^{84}$. En estas, Cabrera compuso un cuadro apologético del desarrollo histórico de la federación, reivindicando sus leyes y el paisaje institucional a que habian dado lugar. E1

81 Muy poco se ha estudiado globalmente el pensamiento transatlántico de Cabrera, aunque recientemente Javier Núñez Pérez ha estudiado la importancia de EEUU en la biografía del personaje: Javier Pérez Núñez, "Memorias sobre América de un exiliado liberal español. Los viajes de Miguel Cabrera de Nevares (1786-1843)", en Manuel Pérez Ledesma, Trayectorias trasatlánticas (siglo XIX): personajes y redes entre España y América, Madrid: Polifemo, 2013, pp. 71-94.

82 José de Onís, "Don Miguel Cabrera de Nevares", en Cabrera de Nevares' Observations of the United States of North America in 1834 ..., The Liberal Revolution in the Hispanic World, University of Colorado, Madrid, Spain, Boulder, Colo.,1968, pp. 17;33-34.

83 Steven Hahn, A Nation Without Borders: The United States and Its World in an Age of Civil Wars, 1830-1910, op. cit., 23-52.

84 José de Onís, "Don Miguel Cabrera de Nevares”, en Cabrera de Nevares' Observations of the United States of North America in 1834 ..., The Liberal Revolution in the Hispanic World, University of Colorado, Madrid, Spain, Boulder, Colo., 1968, p. 30. 
militar progresista presentaba la constitución americana como un artefacto inspiracional, capaz de darle forma al reformismo que estaba tomando cuerpo en España ${ }^{85}$. Las ideas democratizadoras de Cabrera, por cierto, no fueron excepcionales entre los liberales españoles que pusieron su pie sobre el suelo de Norteamérica ${ }^{86}$. Un buen ejemplo de este fenómeno fue el pensador ilustrado Valentín de Foronda, que en 1809 había defendido que las Cortes que habian de reunirse en la península harian bien en aplicar los principios de soberanía popular e igualdad ciudadana que había propugnado Jefferson en sus obras ${ }^{87}$.

De cualquier modo, con el discurso de su Examen, Cabrera de Nevares ponía sus conocimientos en torno a la institucionalidad americana al servicio de las necesidades ideológicas del liberalismo exaltado de los años 30. Como se ha mencionado, sus integrantes se movilizaban en 1835 para combatir el régimen del Estatuto Real de 1834 y garantizar el tránsito a un sistema representativo basado en la doctrina de la soberanía popular. Las contribuciones políticas e intelectuales de Cabrera Nevares a la causa progresista le llevarian a ser elegido diputado para las Cortes constituyentes de 1836, en las cuales invocaría la Constitución norteamericana como modelo al que recurrir puntualmente para organizar un marco institucional estable 88.

Cabrera y sus socios parlamentarios no se limitaron a sugerir el uso del recetario jurídico de los Estados Unidos para el espacio peninsular: desplegaron una visión panhispánica y transatlántica, asegurando que los principios de soberanía popular y articulación federal que estaban presentes en la Constitución de 1787 podían servir a la regeneración política de todos los viejos territorios de la Monarquía, incluyendo a las nuevas repúblicas de habla hispana. Este discurso estuvo muy presente durante las decisivas discusiones parlamentarias en torno al reconocimiento de la independencia de los nuevos territorios ultramarinos que se sostuvieron los tres primeros dias de diciembre de 1836. Cabrera de Nevares, que fue uno de los grandes protagonistas de las mismas y un decidido impulsor del reconocimiento, defendió que la emulación parcial del modelo constitucional estadounidense tenía el potencial de garantizar la soberanía nacional de los pueblos hispanoamericanos frente a los obsoletos intereses dinásticos, oligárquicos y eclesiásticos que pervivian en sus sociedades $^{89}$.

85 Miguel Cabrera de Nevares, Cabrera de Nevares' Observations of the United States of North America in 1834, University of Colorado, Madrid, Spain, Boulder, Colo., 1968 [1834].

86 Un trabajo clásico y fundamental en este aspecto fue producido por el mismo que editó las memorias de Carbera: José De Onis, The United States as Seen by Spanish American Writers, 1776-1890, Gordian Press, New York, 1975.

87 Valentin de Foronda, Apuntes ligeros sobre la nueva Constitucion proyectada por la Magestad de La Junta Suprema espanola: y reformas que intenta hacer en las leyes, Ymprenta de Thomas y Jorge Palmer, Philadelphia, 1809.

88 Para ampliar ver: Rodrigo Escribano Roca, Historias del viejo imperio. Las Américas en el pensamiento histórico de España y Gran Bretaña (1824-1850). Tesis Doctoral. Universidad de Alcalá/Western Sydney University, 2019.

89 Cortes Constituyentes, "Continúa la discusión sobre el reconocimiento de la independencia de las colonias españolas de América y tratados con las mismas", Diario de Sesiones de las Cortes Constituyentes. Legislatura 1836-1837. $\mathrm{N}^{\circ} 45$ (de 447 a 460) $§$ (02-12-1836), p. 453. http://www.congreso.es/est_sesiones/. 
La apelación de Cabrera se correspondía con la interpretación que algunos líderes intelectuales del progresismo, como Agustín Argüelles ${ }^{90}$ y José Manuel Vadillo $^{91}$ habian hecho de las emancipaciones de la América española. Según ellos, estas no habian consistido en un conflicto colonial, sino en una lucha compartida de los pueblos de habla hispana contra sus comunes opresores. Dichos opresores eran identificados con la Corona, la Iglesia y las élites aristocráticas corruptas que habian prosperado bajo su seno. En este contexto, según defendió el propio Argüelles en las sesiones del reconocimiento, la revolución de las Trece Colonias y sus consecuciones constitucionales habian contribuido a hacer a los pueblos hispánicos de ambas orillas del atlántico conscientes de sus libertades y derechos politicos ${ }^{92}$.

Esta postura interpretativa favorecía retóricamente tres proyectos esenciales en la agenda progresista: la democratización del sistema político español, la descentralización de su modelo de gobernanza territorial y el reconocimiento diplomático de las viejas colonias sobre la base de los valores compartidos por los constitucionalistas liberales de ambas orillas del océano. Los abordaremos en orden inverso, según su importancia en el argumentario progresista.

Vale la pena detenerse en el tercer punto. Es posible afirmar que los tratados internacionales con Gran Bretaña cumplieron la función de orientar las ideas de los progresistas en torno a la politica exterior que España debía asumir hacia las repúblicas hispanoamericanas. La experiencia histórica de la enorme prosperidad del Atlántico anglosajón tras el reconocimiento de la independencia de las Trece Colonias tuvo un peso evidente en el debate sostenido por las Cortes Constituyentes durante las mentadas sesiones para el reconocimiento de las emancipaciones americanas celebradas en diciembre de 1836. En el transcurso de las mismas, otro diputado progresista, Dionisio Valdés, defendió que ya no tenía sentido "conquistar el territorio" de las repúblicas. Por el contrario, se trataba de "conquistar á lo menos su comercio" como había hecho "Inglaterra", que ahora había quintuplicado el producto que le reportaba el "sistema colonial" en su libre intercambio con los Estados Unidos. Valdés se declaraba consciente de la debilidad de la industria española, pero depositaba sus esperanzas en un lucrativo intercambio de "productos naturales" entre la Península y las viejas posesiones. Replicar la experiencia post-imperial de Gran Bretaña era la clave para "sacar á nuestro comercio y marina del estado de abatimiento en que se hallan"93. Se esperaba que un marco de acuerdos bilaterales que garantizasen el buen funcionamiento del derecho mercantil y la seguridad de los súbditos españoles en las repúblicas podía compensar a la Monarquía por la pérdida de

90 Agustín Argüelles, Exámen histórico de la reforma constitucional que hicieron las Cortes generales y extraordinarias desde que se instalaron en la isla de León... hasta q. cerraron su Cádiz sus sesiones, vol. I, Imp. Carlos Woods e hijo, Londres, 1835, pp. 344-350.

91 José Manuel de Vadillo, Apuntes sobre los principales sucesos que han influido en el actual estado de la América Del Sud, 3a ed., corr. y aum, Librería de Feros, Cádiz, 1836, pp. 12-16.

92 Congreso de los Diputados. "Discurso del Sr. Argüelles", Diario de Sesiones Congreso de los Diputados. Legislatura 1838-1839. $\mathrm{N}^{\mathrm{o}} 70$ (de 1437 a 1456) $\S$ (31-01-1839), p. 1453. http://www.congreso.es/est_sesiones/.

93 Dionisio Valdés, "Discusión sobre el reconocimiento de la independencia de las colonias españolas de América y tratados con las mismas" en Diario de Sesiones de Las Cortes Constituyentes, vol. 44 (Madrid: Cortes Constituyentes, 1836), pp. 442-443, http://www.congreso.es/est_sesiones /. 
sus territorios. Una aplicación rigurosa del derecho de gentes, basada en la novísima doctrina de la soberanía nacional como principio rector de las relaciones interestatales ${ }^{94}$, tenía el potencial de sustituir el cadáver del viejo imperio por una comunidad mercantil de Estados hispánicos. Otro importante lider del progresismo, Antonio González, se expresó en los mismos términos durante el debate, demandando una réplica del modelo garantista de relaciones postimperiales que habían adoptado las potencias anglosajonas:

“¿y porqué nosotros no podriamos hallar un resultado igual? [al de Estados Unidos y Gran Bretaña] no hay duda en que nuestra marina se aumentaria, y la España prosperaría en toda clase de riquezas. Además, aun cuando el Gobierno no quisiese entrar en este franco tratado ¿podría evitarlo? ¿no es un hecho reclamado por todas las juntas de España? Las juntas de comercio lo han pedido igualmente"95.

El general Torrijos, célebre liberal exiliado en Londres durante los años 20, también había llamado a replicar la experiencia transicional de los anglosajones, que habían logrado, en su opinión, pasar de las violencias fratricidas de la guerra a la constitución de una comunidad post-imperial basada en la comunalidad de identidades, historias e intereses $\mathrm{y}$, sobre todo, en el respeto al derecho internacional:

"In family dissensions there should be a generous forbearance of offence, and honour and glory should be given to him who first extends the hand and proffers a sincere reconciliation. The practical example furnished by the United States of the greater advantage they afford the mother country now, than they did as colonies, should sufficiently convince every Spaniard of the expediency of co-operating in the establishment of peace and harmony between Spaniards and Americans; and the Americans should consider"96.

La admiración por la forma en que los Estados Unidos y Gran Bretaña habian empleado el derecho internacional como un eficaz medio sustitutorio de las relaciones imperiales tuvo un peso importante en el pensamiento progresista, pero marginal si se compara con otro de los grandes campos de instrumentalización del modelo estadounidense: la reivindicación del modelo federal. En general, los escritores progresistas se mostraron positivamente impactados por el sistema territorial de la república transatlántica. Cabrera de Nevares lo dejó patente en sus Observaciones, donde narraba cómo el federalismo norteamericano había logrado conciliar la organización republicana, asociada a pequeños Estados según los patrones clásicos, con una escala imperial por

94 James Mayall, "International Society, State Sovereignty, and National Self-Determination" in John Breuilly (edit.), The Oxford Handbook of the History of Nationalism, Oxford University Press, Oxford, 2013, pp. 2468-2482.

95 Cortes Constituyentes, "Discusión Sobre El Reconocimiento de La Independencia de Las Colonias Españolas de América y Tratados Con Las Mismas," in Diario de Sesiones de Las Cortes Constituyentes, vol. 46 (Madrid: Cortes Constituyentes, 1836), 468, http://www.congreso.es/est_sesiones/.

96 Jose Maria Torrijos y Uriarte, "Preface to the Spanish Edition," in Memoirs of General Miller, in the Service of the Republic of Peru, ed. John Miller, vol. 1 (London: Longmans, Rees, Orme, Brown and Green, 1829), xxx, http://archive.org/details/memoirsofgeneral00milluoft. 
primera vez en la historia. El diputado previó que la federación uniría muy pronto el Atlántico y el Pacífico, dando por descontado que se expandiría sin remedio sobre la enorme faja de territorios controlados por los indigenas que aún se interponian al settlement de sus colonos en el oeste ${ }^{97}$. La dimensión inmensa del territorio controlado por el gobierno de Washington era varias veces reiterada: "Ningún gobierno ejerce jurisdicción territorial sobre una estensión tan grande de superficie compacta, excepto el de Rusia"98. La previsión de su constante expansión continental implicaba la certidumbre de que las provincias incorporadas en calidad de "Territorios" terminarian por convertirse en Estados integrales de la federación, constituyendo así una enorme república continental basada a la par en la igualdad de sus ciudadanos y en la autonomía de sus distintos nodos locales y federales para autogobernarse.

En este sentido, Cabrera trataba de negar los pronósticos fatalistas del absolutismo antiliberal y el moderantismo respecto a la integridad territorial de la federación ${ }^{99}$. Los progresistas nunca aceptaron las expectativas conservadoras de desintegración de los Estados Unidos y reiteraron a lo largo de los años 30 y 40 sus pronósticos de unidad y engrandecimiento para la federación, negando que el seccionalismo $^{100}$ que dividía al norte $\mathrm{y}$ al sur y la descentralización fuesen a suponer un problema de gravedad. En su reseña a Tocqueville de 1846, Ángel Iznardi se afirmaba consciente de las profundas divisiones culturales y políticoeconómicas que mostraban los Estados del Norte, el Sur y el Oeste y, sin embargo, se mostraba convencido de que estas diferencias les conectaban en una relación de complementariedad que las instituciones federales sabrían preservar sine die $e^{101}$.

La mitificación que estos hombres de letras del progresismo realizaron del sistema federal consagrado por la Constitución de 1787 se explica bien por su particular posicionamiento en el tablero político español. Desde su génesis en las dos primeras décadas del siglo XIX, el liberalismo español había fundamentado su poder en su inserción capilar en los municipios y provincias de España. Las Juntas municipales y provinciales convocadas con motivo de la invasión napoleónica habían sido el primer foro que había situado a los liberales en el centro de la toma de decisiones politicas. Desde entonces, el liberalismo exaltado habia encontrado su base social en los centros urbanos distribuidos por el territorio español. Asimismo, durante los años 30 y 40 los progresistas hicieron de la movilización de juntas locales y del control de los ayuntamientos sus instrumentos preferentes de disputa electoral y de control del poder, todo ello

97 Miguel Cabrera de Nevares, Cabrera de Nevares' Observations of the United States of North America in 1834, op.cit., p. 99.

98 Miguel Cabrera de Nevares, Cabrera de Nevares' Observations of the United States of North America in 1834, op.cit., p. 100.

99 Ver apartado siguiente.

$100 \mathrm{El}$ término hace referencia a las lealtades enfrentadas entre la soberanía federal y estatal que se daban en los Estados de la federación, especialmente respecto de la divisoria que separaba al norte del sur esclavista. Para una explicación satisfactoria del fenómeno ver: Michael E Woods, Bleeding Kansas: Slavery, Sectionalism, and Civil War on the Missouri-Kansas Border, Routledge, New York, 2017.

101 Ángel Iznardi, "Gobierno y costumbres de los Estados-Unidos. Análisis de La obra de M. Tocqueville, titulada, De la Democratie en Amerique", op.cit., p. 3. 
frente a las instancias de la Corona y las administraciones centrales, que fueron una esfera de influencia más eficazmente ocupada por el moderantismo102. En este contexto, importantes sectores del liberalismo exaltado abogaron por un modelo estatal descentralizado, asociando entre sí las ideas de libertad individual, autonomía municipal y soberanía popular y oponiéndolas figurativamente al gobierno absolutista y a la concentración de poderes. Fue este contexto de reivindicación descentralizadora en el cual el aparente triunfo del modelo federal americano se instituyó como mito político inspiracional. En esta línea argumentaron el propio Iznardi y los artículos de El Eco del Comercio ${ }^{103}$.

Las vindicaciones del sistema federativo estadounidense habían asomado ya durante la década de los 20 , en el contexto de la discusión en torno al modelo territorial que debía adoptar el imperio español ante el reto de las guerras de independencia en América. Fue precisamente Miguel Cabrera de Nevares quien, como parte de sus servicios a la Secretaría de Ultramar durante el Trienio Liberal (1820-1823), propuso un esquema de reorganización territorial inspirado en el federalismo estadounidense consagrado por la Carta de 1787, todo ello para evitar las emancipaciones ultramarinas. En su Memoria sobre el Estado actual de las Américas, había sugerido negociar la creación de una "Gran Confederación Hispano-Americana"104. Esta, según su proposición, debía construirse sobre la base de la independencia de los países de ultramar. Estos Estados, junto con la propia España, tendrían cada uno "su Congreso y su Constitución particular", pero a su vez se reunirian en un "Congreso Federal", compuesto de diputados enviados por cada uno de los países integrantes. La emancipación negociada y el posterior proceso federativo sustituirian a la obsoleta legitimidad confesional y consuetudinaria de la Corona hispánica. La alternativa, inspirada en el experimento de los Estados Unidos, sería un nuevo contrato social y territorial, en virtud del cual Fernando VII podría detentar el título de "Rey de España y Protector" de la confederación ${ }^{105}$.

Las menciones al éxito territorial estadounidense se consolidarian de algún modo en la retórica constitucional de un sector del progresismo en la década de los 30. De hecho, el diputado por Barcelona Domingo María Vila, que ejercía como catedrático de jurisprudencia, defendió el papel ejemplar del federalismo norteamericano en las discusiones parlamentarias sobre el modelo territorial que debía aplicarse en el nuevo texto constitucional de 1837. En la sesión de las Cortes Constituyentes del 22 de diciembre de 1836 el diputado sugirió la posibilidad de inspirarse en los modelos de la federación estadounidense y de la brasileña para resolver el problema de la articulación política de las provincias y municipios españoles. Las experiencias federales transatlánticas probaban, decía,

102 Adrián Shubert, "El progresismo durante la regencia de Espartero (1840-1843)", Historia constitucional: Revista Electrónica de Historia Constitucional, $\mathrm{n}^{\circ}$ 17, 2016, 355-358; Daniel Aquillué Domínguez, "El liberalismo en la encrucijada: entre la revolución y la respetabilidad 18331843", Tesis Doctoral, Universidad de Zaragoza, 2017, pp. 296-98.

103 "El pueblo gobernado por el pueblo (tercer diálogo entre un periodista y un artesano", El Eco del Comercio, 30 de octubre de 1838, 1; Ángel Iznardi, "Gobierno y costumbres de los EstadosUnidos. Análisis de La obra de M. Tocqueville, titulada, De la Democratie en Amerique", op.cit., p. 3.

104 Miguel Cabrera de Nevares, Memoria sobre el estado actual de las Américas, y medio de pacificarlas, Imprenta de don José del Collado, Madrid, 1821, p. 5.

105 Miguel Cabrera de Nevares, Memoria sobre el estado actual de las Américas, y medio de pacificarlas, op.cit., p.54. 
que era posible combinar "un sistema de unidad de centralización política" con una "independencia y separación provincial en la parte administrativa y económica". Decía que gracias a estos ejemplos del mundo americano ya no se podia afirmar que los gobiernos federales fuesen una utopía filosófica, como también confirmaba el hecho de que el Imperio británico estuviese copiando el sistema estadounidense para federar a sus colonias canadienses ${ }^{106}$. Esta declaración demuestra el peso que tuvo la historización de los procesos políticos del mundo transatlántico en los procesos constituyentes españoles.

No obstante, la invocación de Vila demuestra que el uso que le dieron los progresistas al federalismo norteamericano se basaba en una interpretación del mismo altamente simplificadora y selectiva. Como han explicado Florencia Peyrou107 y José María Portillo108 respecto a las ideas federales del primer liberalismo español y del movimiento republicano de mediados de siglo, el progresismo postrevolucionario equiparó el federalismo a la descentralización administrativa y a la autonomía de los ayuntamientos para desarrollar políticas a escala meramente local. Los progresistas nunca aspiraron a incorporar el reparto de competencias y atribuciones soberanas que en la práctica implicaba el modelo estadounidense. De hecho, la idea de federación del liberalismo radical español, como explica Manuel Suárez Cortina, respondió más a clivajes ideológicos que identitarios o territoriales; esto es, los sectores republicanos y progresistas tendieron a ver la federación más como una garantía de participación popular en la politica, que como un medio de gobernanza o de vertebración de los diversos intereses regionales españoles ${ }^{109}$. Es decir, no era una idea federal tan asentada en el reconocimiento de la diversidad de tradiciones, jurisdicciones y fueros que habian articulado a la Monarquía, como en el principio de control democrático a los poderes centrales del Estado. A este respecto, como apunta Manuel Chust, ya desde la Cortes de Cádiz no se puso en duda la naturaleza compacta de la soberania nacional. La mayor parte de los liberales españoles rechazaron un esquema de reparto de poder territorial que fuese más allá de una descentralización irradiada desde el centro, fracasando sistemáticamente los proyectos genuinamente federales o confederales ${ }^{110}$.

Así, el uso doctrinal del modelo federal estadounidense se vio limitado por el dogma progresista de la unidad nacional. Su significado fue negociado y alterado, convirtiéndolo en repositorio argumental para defender el municipalismo y el principio de soberanía popular frente a la prerrogativa regia. De cualquier modo,

106 “Cortes. Estamento de Procuradores. Sesión 13 enero", La Gaceta de Madrid, 14 de enero de $1836,1-2$.

107 Florencia Peyrou, "Los orígenes del federalismo en España: del liberalismo al republicanismo, 1808-1868”, Espacio, tiempo y forma. Serie V, Historia contemporánea, n²2, 2010, pp. $261-271$.

108 Jose María Portillo Valdés, “Federalismo. España” en Javier Fernández Sebastián (Edit.), Diccionario politico y social del mundo iberoamericano, Centro de Estudios Politicos y Constitucionales, Madrid, 2015, pp. 503-504.

109 Manuel Suárez Cortina, "Estado, Nación y Federalismo en Europa del Sur y América Latina”, en Manuel Súarez Cortina (Edit.), Federalismos: Europa del Sur y América Latina en perspectiva histórica, Comares, Granada, 2017, pp. 9-10.

110 Manuel Chust, "The National Road of the Cádiz Cortes: Anticolonialism, Liberalism, Nation and State", in Paul Garner and Angel Smith (Edits.), Nationalism and Transnationalism in Spain and Latin America, 1808-1923, University of Wales Press, Cardiff, 2017, pp. 32-33, 42. 
no se puede desconocer la importancia que tuvieron los relatos progresistas sobre el éxito territorial de la Unión a la hora de fijar los horizontes municipalistas del liberalismo exaltado de los años 30. No es casual que, como apunta Adrian Shubert, cuando en 1840 la regente María Cristina y los moderados trataron de limitar el poder de los gobiernos locales con la Ley de Ayuntamientos, las corporaciones municipales controladas por el progresismo, como Zaragoza y Barcelona, apelasen a la regencia de Espartero comparándolo en sus manifiestos y ceremonias públicas con un Washington español, destinado a rescatar las libertades derivadas del autogobierno local en la Monarquía111. De esta forma, se hace posible apreciar que la imagen de los Estados Unidos y su asociación con la descentralización del poder y las libertades municipales se había instalado poderosamente en el patriotismo constitucional de los exaltados.

\subsection{Entre la admiración y la cautela: interpretaciones progresistas del constitucionalismo democrático.}

La interpretación del federalismo americano vino acompañada en el pensamiento progresista de todo un alegato teleológico en torno a la modernidad social, económica y tecnológica del país. Las referencias al sistema constitucional de los Estados Unidos se fundamentaron sobre una mitificación de su historia republicana y del tipo antropológico del ciudadano americano. En sus Observaciones, Cabrera de Nevares subrayaba cómo a la disponibilidad de un espacio repleto de potencialidades económicas y de las tecnologías necesarias para explotarlo y ocuparlo se habia unido la revolución demográfica que estaba viviendo el país, con una población que se había quintuplicado en los últimos cuarenta años. Haciéndose eco de los mitologemas cultivados por los adalides americanos del Manifest Destiny ${ }^{112}$, Nevares achacaba este crecimiento sin parangón al aluvión de inmigrantes europeos que, expulsados por las injustas condiciones sociales que sancionaban diariamente las monarquías del viejo mundo, acudian a disfrutar de las tierras disponibles y de las garantías de un sistema legal plenamente democrático: "Tierras nuevas, baratas y abundantes, juntamente con la protección y amparo de instituciones libres, son los elementos naturales de un aumento rápido de población"113.

Según las Obervaciones, los mundos del oeste americano procuraban una transformación que sintetizaba el proyecto emancipador de todos los demócratas del espacio atlántico: de ser siervos, obreros y campesinos oprimidos por los regímenes de injusticia y la falta de distribución del ingreso que predominaban en las monarquías europeas, los emigrantes se convertian casi de inmediato en propietarios medianos que disfrutaban de todos los derechos políticos y civiles que aseguraba la ciudadanía de la Unión. El colono del oeste americano se convertía en la imagen mítica del hombre nuevo: una mezcla idónea entre la independencia primigenia del buen salvaje y las condiciones de sociabilidad del

111 Adrian Shubert, Espartero, el Pacificador, Galaxia Gutenberg, Barcelona, 2018, pp. $218-20$.

112 Susan Mary Grant, "State-Building and Nationalism in Nineteenth Century USA" in John Breuilly (Edit.), The Oxford Handbook of the History of Nationalism, Oxford University Press, Oxford, 2013, pp. 1814-1834.

113 Miguel Cabrera de Nevares, Cabrera de Nevares' Observations of the United States of North America in 1834, op.cit., p. 117. 
sujeto cristiano y civilizado. Su tránsito por el territorio americano equivalía, en una retórica que se hacía eco de los mitos fronterizos de los pensadores estadounidenses, a un rito de paso del viejo mundo de barreras corporativas y privilegios venales al nuevo mundo de los derechos individuales y la igualdad legal114. Cabrera de Nevares lo expresaba con claridad meridiana: "A mi entender, ninguna condición, considerada en sí misma, promete un bienestar más dulce, ni tiene más grande tendencia á la virtud y á la independencia, que la de estos hacendados del Occidente de los Estados Unidos con sus numerosos, robustos y felices hijos a su alrededor" ${ }^{115}$. El propietario piadoso, independiente, fiel a su familia nuclear, de moderada riqueza, y hecho a sí mismo, era el ideal de masculinidad que, según Cabrera de Nevares, se realizaba cotidianamente en el suelo americano, sustentando además el "espíritu general" de su institucionalidad democrática, cimentado por el ejercicio constante de la "independencia" que se aplicaba a nivel individual, local y federal con el mismo convencimiento ${ }^{116}$. El pensador progresista llegaba a afirmar que el colono democrático de la frontera norteamericana admitía comparaciones con los colonizadores y conquistadores que, en el siglo XVI, habian ganado Nueva España y la América del sur para España:

\begin{abstract}
"ninguna condición humana es más susceptible de abundancia, de independencia, y de los goces más puros que puede ofrecer la tierra, que la del morador de una habitación de madera, que cultiva un terreno que es suyo propio, y que no ha sido surcado todavía por la reja del arado [...] Con cuanto interés no leeríamos ahora el diario de uno de los primeros colonos de la opulenta y populosa Méjico, dando los pormenores diarios de sus progresos en fábricas, cercar, y adelantar desde la primera necesidad de un albergue para guarecerse del rigor de los elementos hasta llegar al estado de comodidad, riqueza y elegancia! El alma se deleita cuando vá siguiendo un caudaloso rio hasta su humilde nacimiento; del mismo modo cuando observa el adelantamiento, grandeza y esplendor de los Estados hasta la primera semilla de su origen" 117 .
\end{abstract}

Con esto, Cabrera de Nevares mostraba la voluntad de subsumir los mitos imperiales españoles en un ideario propio del colonialismo decimonónico, muy cercano a las conceptualizaciones de la imaginería settler, según la cual la expansión de las sociedades europeas no solo desplazaría legítimamente al resto de pueblos, sino que, además, tendría el poder de regenerar espiritualmente a los

114 Como ha explicado Anthony Smith, esta fue una tradición discursiva que se consolidó en Norteamérica desde la fundación de las colonias hasta configurar el relato seminal de Turner sobre la frontera americana: Alfred D. Smith, Chosen Peoples: Sacred Sources of National Identity, Oxford University Press, Oxford, 2013, p. 140.

115 Miguel Cabrera de Nevares, Cabrera de Nevares' Observations of the United States of North America in 1834, op.cit., pp. 134-136.

116 Miguel Cabrera de Nevares, Cabrera de Nevares' Observations of the United States of North America in 1834, op.cit., p. 37.

117 Miguel Cabrera de Nevares, Cabrera de Nevares' Observations of the United States of North America in 1834, op.cit., p. 133. 
decadentes mundos europeos ${ }^{118}$. Las sociedades ultramarinas se convertían en Europas desplazadas al futuro que, ocupando las naturalezas vírgenes, reproduciendo la nacionalidad metropolitana, mundializando los mercados, aplicando los principios del liberalismo político y aliviando las tensiones sociales de Europa, asegurarian un futuro global venturoso ${ }^{119}$. De forma muy interesante, la comparación de arquetipos imperiales realizada por Cabrera muestra su intento de equiparar una masculinidad de signo españolista, encarnada en los conquistadores, con el ideal de libertad individual y desarrollo civilizatorio que representaba el colono americano. Esta mediación simbólica de modelos de masculinidad puede arrojar importantes pistas para el análisis de este campo incipiente de estudio en las culturas políticas de la España decimonónica ${ }^{120}$.

De cualquier modo, Iznardi respaldó a Cabrera de Nevares en su mitificación en clave liberal del experimento americano, citando y actualizando para ello las narrativas americanistas de clásicos como John Locke y el cronista Nathaniel Morton. Norte-América era representada por el periodista y editor como un espacio destinado a acoger a las humanidades decimonónicas para que estas llevaran a término la epopeya civilizatoria iniciada por los colonos del Mayflower en el siglo XVII. A los Pilgrim Fathers les representaba el periodista en clave secular, sin hacer mención de toda su evidente religiosidad puritana: como miembros expatriados de una sociedad civil oprimida por la tiranía politica y eclesiástica de los Estuardo, que se habian trasladado a los paisajes indómitos de ultramar para fundar una comunidad que conservaba las semillas de desarrollo de la civilización cristiano-occidental, sin participar de los vicios que había incubado en las Cortes regias de Europa ${ }^{121}$.

Así aparecía también reflejado, de nuevo, en el relato de Cabrera de Nevares. Una vez los colonos del Mayflower habian constituido sus "ciudades sobre la colina", decía, se habían consagrado a la perpetuación de la autonomía individual y la libertad político-religiosa ${ }^{122}$. Los Estados Unidos eran la consecuencia de un desarrollo colonial que había consistido en la consolidación de los principios asamblearios y esencialmente ilustrados de los pioneros:

"todo cuanto hay de elegante, de poderoso y de adelantado en los Estado Unidos tuvo la misma cuna en sus principios, y que por estos medios han llegado a ser lo que son; que el tránsito de chozas a mansiones cómodas, y de plantaciones rústicas a ciudades opulentas, se ha verificado en nuestros días, con una rapidez tan asombrosa que raya los términos de lo increíble; que sus poblaciones han nacido como por encantamiento del centro de sus bosques

118 Algunos estudios de gran relevancia sobre la mitologia settler: Craig Yirush, Settlers, Liberty, and Empire: The Roots of Early American Political Theory, 1675-1775 Cambridge University Press, Cambridge, 2011.

119 Miguel Cabrera de Nevares, Cabrera de Nevares' Observations of the United States of North America in 1834, op.cit., p. 132.

120 Xavier Andreu Andreu Miralles, "Introducción al dosier. Nación y masculinidades en la España contemporánea", Studia historica. Historia contemporánea, n 38, 2020, pp. 5-15.

121 Ángel Iznardi, "Gobierno y costumbres de los Estados-Unidos. Análisis de La obra de M. Tocqueville, titulada, De la Democratie en Amerique", op.cit., p. 3.

122 Miguel Cabrera de Nevares, Cabrera de Nevares' Observations of the United States of North America in 1834, op.cit., p. 133. 
apenas accesibles a los rayos del sol; y que el germen de estos primeros trabajos lleva consigo el desarrollo de un vasto y floreciente imperio, al cual apenas puede señalar límites la imaginación"123.

La prensa progresista contribuyó a socializar una visión romántica y triunfalista del desarrollo histórico del constitucionalismo americano, vinculándola también con su pasado colonial. En El Eco del Comercio, por ejemplo, aparecieron efemérides con motivo del aniversario de la proclamación de independencia de los Estados Unidos. En estas se reiteraba el origen democrático de la federación y su condición como refugio de poblaciones perseguidas. Su independencia se narraba como una rebelión legítima ante la opresión monárquica y se subrayaba su transformación de una pequeña comunidad litoral a un imperio hemisférico destinado a unir Europa y Asia en un solo mercado mundial. Sus editores también subrayaban que esta gesta se estaba completando con la ocupación masiva del espacio continental, el desarrollo sin precedentes de los ferrocarriles y el crecimiento demográfico ${ }^{124}$. Para redondear esta historización mitológica tampoco faltaron micro-relatos, como los que desde El Guardia Nacional compartieron con los lectores semblantes heroicos de los filántropos de la historia americana, como William Penn, vinculándolos triunfalmente con el triunfo global del gobierno representativo ${ }^{125}$.

Tanto Cabrera de Nevares como Iznardi extendieron indefectiblemente sus alabanzas al pasado democrático de la federación a los sistemas normativos que imperaban en la misma, subrayando de constante el isomorfismo entre sus leyes y sus prácticas socioculturales. La idea era que la democracia americana se cimentaba sobre el espíritu práctico de sus ciudadanos y sobre su tendencia a evaluar positivamente la realidad ${ }^{126}$. Esto redundaba en que la Constitución y las leyes del país proporcionasen a sus habitantes unas condiciones de existencia jurídica que podian convertirse en un horizonte perseguible para todos los regímenes políticos del mundo: la libertad de cultos, la separación general de la Iglesia y el Estado y el aseguramiento de condiciones legales que permitian un asociacionismo constante ${ }^{127}$. A dichas instancias se unía, según Cabrera, la influencia benéfica de la opinión pública, que con su socialización de los juicios de la mayoría social suplia la ausencia de normas estrictas que regulasen el comportamiento social128. Iznardi sintetizaba todas estas alabanzas con rotundidad: "¡Qué lección ofrecen hoy los Estados Unidos a los que creían

123 Miguel Cabrera de Nevares, Cabrera de Nevares' Observations of the United States of North America in 1834, op.cit., p. 132.

124 “Efemérides. Estados Unidos”, El Eco del Comercio, 10 de julio de 1847, 3.

125 “Guillermo Penn”, El Guardia Nacional, 21 de marzo de 1839, 1-2.

126 Miguel Cabrera de Nevares, Cabrera de Nevares' Observations of the United States of North America in 1834, op.cit., p. 138.

127 Ángel Iznardi, "Gobierno y costumbres de los Estados-Unidos. Análisis de La obra de M. Tocqueville, titulada, De la Democratie en Amerique", op.cit., p. 4; Miguel Cabrera de Nevares, Cabrera de Nevares' Observations of the United States of North America in 1834, op.cit., p. 117-118.

128 Miguel Cabrera de Nevares, Cabrera de Nevares' Observations of the United States of North America in 1834, op.cit., p. 138. 
entonces y predican todavía en Europa que es incompatible la libertad con la virtud y con el orden público!" ${ }^{129}$.

En este contexto, la Constitución de 1787 enfocó la atención de estos comentaristas del progresismo, que la sometieron a una verdadera descripción laudatoria, dando por supuesta su condición como reguladora efectiva de las relaciones sociales, y como instrumento garante de la unidad de la "Confederación nacional" y de la libertad política y religiosa. Según las Observations de Cabrera de Nevares, la carta aprobada era "tal vez, la Constitución más sencilla y más bien adaptada, que jamás se ha escrito sobre libertad política"130.

Los intérpretes progresistas centraron su atención en los elementos más progresivos de la Constitución americana, siguiendo una estrategia hermenéutica radicalmente distinta a la de sus homólogos del Partido Moderado, que, como veremos, siempre celebraron sus elementos más conservadores. Por el contrario, Cabrera, Iznardi y la prensa exaltada subrayaban las provisiones de la Constitución en torno al sufragio universal, la democracia electiva, la separación de poderes y la atribución repartida de competencias a las instancias federales y de cada Estado particular ${ }^{131}$. Las Observaciones de Cabrera, asumiendo el lenguaje utilitarista y filo-ilustrado de los propios redactores de la Constitución, la celebrarían como un dechado de sabiduría republicana, subrayando su capacidad para garantizar la comodidad y el bienestar material del ciudadano: "Ninguna comunidad ha existido tal vez que pueda de buena fe atribuir á una Carta de gobierno, una suma más grande de felicidad y prosperidad política que los Estados Unidos"132.

Iznardi, también apeló en su reseña de Tocqueville al poder ejemplificador del constitucionalismo americano en lo referente a las formas de organización de los procesos electorales. En este ámbito intentó, como lo había hecho en sus ediciones constitucionales, sostener una identificación entre el constitucionalismo liberal español y el americano. El publicista afirmaba que tanto las disposiciones electorales de la Constitución estadounidense como las de la Constitución española de 1812, habian demostrado que el modo de elección más justo y seguro era el que daba el sufragio universal indirecto. Iznardi afirmaba que durante su etapa como editor de El Eco del Comercio en 1837 ya había defendido, junto a pensadores liberales como Fermín Caballero y Manuel Fuente Andrés, este sistema contra los del voto censitario y la elección directa. Según su opinión, el modelo estadounidense, de la misma forma que "la Pepa", había garantizado con el sufragio universal indirecto que los representantes fueran fieles a la voluntad mayoritaria de las naciones a las que gobernaban, pero

129 Ángel Iznardi, "Gobierno y costumbres de los Estados-Unidos. Análisis de La obra de M. Tocqueville, titulada, De la Democratie en Amerique”, op.cit., p. 3.

130 Miguel Cabrera de Nevares, Cabrera de Nevares' Observations of the United States of North America in 1834, op.cit., p. 130.

131 Méndez de Vigo, España y América en progreso, op.cit., 127-30.

132 Miguel Cabrera de Nevares, Cabrera de Nevares' Observations of the United States of North America in 1834, op.cit., p. 131. 
depurando las pulsiones demagógicas de los elementos populares y traduciendo en un hecho legislativo solo sus "pensamientos más elevados"133.

Con esta lectura de la Constitución de 1787, Iznardi exhibía su adscripción al sector más moderado del Partido Progresista, que, durante los debates en torno a las disposiciones electorales de la Constitución de 1837, se había opuesto al voto directo demandado por los exaltados más democráticos. Así, la sección del progresismo a la que pertenecía Iznardi adoptó en este caso una postura doctrinal consistente en subrayar los mecanismos moderadores que las leyes americanas sancionaban. Con ello el periodista dotaba de sustento simbólico al ideal politico de la intelligentsia progresista. Este se centraba en la consecución de un sistema representativo que facilitase la tutela moral e intelectual de una élite burguesa y reformadora, la cual debía liderar el cambio político en base a la actividad legislativa, limitando el afán revolucionario de las clases populares ${ }^{134}$. Estos imaginarios legales se veían reforzados por las asociaciones conceptuales, patentes en la Colección editada por Iznardi, entre la Constitución de 1812 y la Constitución de 1787135. El publicista vinculaba el fallido proyecto de democratización monárquica de las décadas anteriores con el exitoso experimento legal de la república americana. De esta forma, interpretaba que la perpetuación de la democracia americana probaba que los principios fundamentales del constitucionalismo exaltado español, a pesar de su fracaso puntual, se realizarian necesariamente en un futuro próximo.

Finalmente, la Constitución de 1837 recogería un sistema de voto directo136 y las leyes electorales derivadas de su laxo articulado sancionaron el voto censitario y capacitario ${ }^{137}$, sin alcanzar una fisonomía definitiva ${ }^{138}$. Poco tuvieron que ver, por tanto, con las aspiraciones de los defensores del sufragio universal masculino e indirecto. De ahí la lamentación nostálgica que arrojaba Iznardi ya en 1846. Sin embargo, las consideraciones del veterano periodista evidencian que la imagen de los Estados Unidos se convirtió en un eje de discusión esencial para que el progresismo definiese y legitimase sus ideas en torno al ciudadano elector y la extensión del voto.

En cualquier caso, si algo distinguió a los imaginarios progresistas en torno al constitucionalismo americano de sus homólogos demócratas y republicanos,

133 Ángel Iznardi, "Gobierno y costumbres de los Estados-Unidos. Análisis de La obra de M. Tocqueville, titulada, De la Democratie en Amerique”, op.cit., p. 4.

134 María Cruz Romeo Mateo, "La tradición progresista: historia Revoluciónaria, historia nacional” en Manuel Suárez Cortina (Edit.), La redención del pueblo: la cultura progresista en la España liberal, Servicio de Publicaciones Universidad de Cantabria, Santander, 2006, pp. 93-94.

135 Ángel Iznardi, Colección de Constituciones, op. cit.

136 Constitución de la Monarquía española. Año de 1837. Original manuscrito 1837 , Tít. IV Art.22.

137 Es decir, la restriccción del sufragio y de la capacidad para tomar decisiones politicas solo a los sectores concebidos como intelectualmente más dotados. Ver: ; Alan S Kahan, Liberalism in Nineteenth-Century Europe: The Political Culture of Limited Suffrage, Palgrave Macmillan, Basingtoke, 2003, pp. 6-7.

138 Miguel Ángel Presno Linera, "El sistema electoral español desde sus origenes hasta la Constitución de 1978", Historia constitucional: Revista Electrónica de Historia Constitucional, $\mathrm{n}^{\circ} 19,2018$, pp. 95-96. 
fue su carácter altamente relativo $\mathrm{y}$ selectivo. $\mathrm{Si}$ representantes del republicanismo liberal y socialista, como Pedro Méndez de Vigo ${ }^{139}$ o Fernando Garrido ${ }^{140}$, defendieron una adopción integral del modelo legal estadounidense, los pensadores progresistas relativizaron la aplicabilidad de su arquitectura jurídico-política en España y en las repúblicas desgajadas del imperio español.

Cabrera de Nevares, adscrito a un paradigma historicista que predicaba la necesidad de adaptar la democracia representativa a las tradiciones jurídicas "nacionales"141, afirmaba que las leyes estadounidenses no podian trasplantarse en puridad al suelo de todos los países del mundo atlántico: "pero si esta misma Carta se quisiese imprudentemente adoptar en otra nación, cuyas circunstancias no fueran las mismas que en los Estados Unidos, ella sería un instrumento de destrucción y muerte"142. En sus Observaciones aplicaba la idea que los historiadores liberales del derecho, como Martínez Marina, habian defendido durante las décadas anteriores. En opinión de este, que fue secundado por los relatos histórico-políticos de Agustín de Argüelles y Modesto Lafuente ${ }^{143}$, el advenimiento de un régimen jurídico basado en el principio de la soberanía popular en España debía enraizarse en las tradiciones de gobierno representativo que, según su interpretación, habian sido características de las Cortes y leyes medievales que habían regido en las Coronas de Castilla y Aragón ${ }^{144}$. Este mito historicista fue muy común en las culturas políticas del liberalismo europeo postrevolucionario, que se postularon como una vía alternativa las tabulas rasas propuestas desde el contractualismo radical y el socialismo. En este sentido, la postura de los progresistas españoles fue similar a la que mantuvieron los whigs ingleses. Si bien intelectuales como John Howard Hinton alabaron el modelo constitucional engendrado con la independencia estadounidense, lo afirmaron inaplicable teniendo en cuenta la constitución histórica de Gran Bretaña ${ }^{145}$.

También el diputado Gabino Gasco aclaró, en su defensa de la Constitución angloamericana, que no la creía exportable en puridad a la Monarquía española. Gasco afirmaba que el verdadero valor del modelo estadounidense radicaba en demostrar la validez del constitucionalismo, más allá de sus necesarias variaciones respecto de la forma de Estado: "Lejos de mi toda segunda intención:

139 Méndez de Vigo, España y América en Progreso, op.cit., pp. 83-89. 31.

140 Garrido, La humanidad y sus progresos o la civilización antigua y moderna. Tomo I, op.cit., p.

141 Maria Sierra Alonso, “Legisladores hereditarios”: la historia como naturaleza en la ley liberal' en María Sierra Alonso y María Cruz Romeo (Edits.), La España liberal 1833-1874, Marcial Pons, Madrid, 2014, pp. 23-50.

142 Miguel Cabrera de Nevares, Cabrera de Nevares' Observations of the United States of North America in 1834, op.cit., p. 154.

143 Argüelles, Exámen histórico de la reforma constitucional que hicieron las Cortes generales y extraordinarias desde que se instalaron en la isla de León... hasta q. cerraron su Cádiz sus sesiones, op.cit.; Modesto Lafuente, Historia general de España, Establecimiento Tipográfico de Mellado, Madrid: 1850, http://archive.org/details/bub_gb_OSwJAAAAQAAJ.

144 Francisco Martínez Marina, Teoría de Las Cortes ó Grandes Juntas Nacionales de los Reinos de León y Castilla: con algunas observaciones sobre La Lei Fundamental de la Monarquia Española ... Promulgada en Cádiz á 19 de Marzo de 1812, Imprenta de Fermín Villalpando, Madrid, 1813.

145 John Howard Hinton, The History and Topography of the United States of North America, from the Earliest Period to the Present Time ..., vol. I, S. Walker, Boston, 1834, pp. 280-344. 
el gobierno republicano no conviene actualmente á la España. (...) Lo que conviene á la España en la época actual es la constitución"146. Con esto, Gasco reconocía su exégesis selectiva del corpus doctrinal del constitucionalismo estadounidense, afirmando que solo se debía aspirar a adaptar creativamente algunos de sus elementos a la Monarquía constitucional española.

De cualquier modo, los argumentarios precedentes demuestran la compleja mediación significativa a la que sometieron los pensadores progresistas el modelo constitucional norteamericano. Este fue puesto al servicio de su necesidad de conciliar el gobierno representativo con el mantenimiento de la institución monárquica y con la capacidad para generar consensos con el moderantismo. Otro ejemplo valioso de este fenómeno es rastreable en la sesión del Congreso de los Diputados del 29 de abril de 1841. Durante aquella jornada, en el contexto del debate para instituir la nueva Regencia progresista, el diputado Miguel Alejos Burriel leyó en alta voz la Constitución de Estados Unidos. El diputado progresista, defendiendo una tesis ampliamente compartida entre un sector del Partido, afirmó que la Regencia debía repartirse entre tres sujetos, puesto que el sistema político español aún no estaba maduro para concentrar todos los poderes en un solo jefe de Estado.

La idea de Burriel era que si los Estados Unidos concentraban el poder ejecutivo en la figura del presidente sin temer a la tiranía era gracias al funcionamiento efectivo de los controles parlamentarios e institucionales fijados por su constitución: "Aquí tenemos que los presidentes y vice-presidentes de aquella república son como los porteros de nuestras oficinas, pues se les exige la responsabilidad, como se pudiera hacer aquí á un escribiente"147. También achacaba este control del ejecutivo al respeto que profesaban los políticos de la Unión angloamericana por las normas emanadas de la institucionalidad democrática. Por el contrario, alegaba que la Monarquía española, cuyos elementos populares y sus élites se mantenían fieles a la cultura autocrática del viejo régimen, aún precisaba de un ejecutivo independiente del poder parlamentario. Esto implicaba que la única forma de limitar el poder de la Regencia era convertirla en una suerte de triarquía ${ }^{148}$. A efectos del presente artículo, es interesante subrayar el empleo de la constitución estadounidense como elemento normativo referencial y como herramienta retórica, pero también el hecho de que Burriel la presentase como inaplicable en el contexto de la Monarquía española.

En la misma linea se puede leer la obra publicada en 1842 con el título Monarquia constitucional: dedicada a los pueblos hispano-americanos que quieran constituirse bajo un sistema monárquico-constitucional. El autor era el liberal exaltado Tomás Bertrán i Soler, polígrafo y decidido participante en las movilizaciones orquestadas por el asociacionismo y el municipalismo progresista durante las décadas previas. El libro, como su título rezaba, no era otra cosa que una propuesta experimental de constitución que pretendia servir de

146 Gabino Gasco, "Prólogo", en Achille Murat, Esplicación de los principios del gobierno republicano, del cual ha sido perfeccionado en los Estados Unidos de América, op.cit., p. 8.

147 Miguel Alejos Burriel, "Continúa la discusión sobre el número de personas que habian ido formar la Regencia”, Diario de Sesiones de las Cortes, vol 35, 1841, p. 637.

148 Miguel Alejos Burriel, "Continúa la discusión sobre el número de personas que habian ido formar la Regencia”, op.cit., p. 638. 
orientación para la creación de monarquías parlamentarias en las "repúblicas hispanoamericanas"149.

Su propuesta concreta era la de un Estado en el que la "nación" detentase la soberanía, pero reservando el poder ejecutivo a la Corona en exclusiva. Esta debía ser electiva y vitalicia ${ }^{150}$. El poder legislativo estaba compuesto por dos cámaras. En primer lugar, un senado con funciones de representación territorial y corporativa, que debía acoger a la nobleza creada para servir como brazo aristocrático del estado monárquico. En segundo lugar, un parlamento que sirviera a la representación nacional censitaria ${ }^{151}$. La articulación territorial quedaba vertebrada en un sistema vertical de administraciones que iban de la Corona, a las juntas departamentales y las municipalidades, cada una con competencias específicas ${ }^{152}$. En las primeras páginas de la obra Bertrán se declaraba admirador de la constitución republicana de los Estados Unidos, pero afirmaba que esta no se ajustaba a las tradiciones de los pueblos de habla hispana, cuya fisonomía social requería de ejecutivos fuertes que centralizasen las relaciones sociales y garantizasen el imperio de la ley ${ }^{153}$.

La propuesta historicista de Bertrán es sintomática de la consolidación del monarquismo como atributo sustancial del modelo parlamentario defendido desde la cultura constitucional del progresismo. Estas posturas explican, en buena medida, la escisión que se produce en el ala radical del Partido Progresista, dando a luz en 1849 a un Partido Democrático cuyos miembros postularán una importación más integral de las formas jurídico políticas de la Unión angloamericana. Al mismo tiempo, la relativización en clave monárquica de la legislación americana estableció un nexo inestable entre los imaginarios americanistas de los progresistas y los de la otra cultura constitucional que se consolidó en el seno del liberalismo postrevolucionario: el moderantismo.

\section{EL ESPEJO INVERTIDO. LOS ESTADOS UNIDOS EN EL CONSTITUCIONALISMO MODERADO.}

\subsection{Tradiciones anglosajonas: la revolución americana desde el historicismo moderado.}

La cultura constitucional de los moderados tuvo una relación aún más ambivalente que la del progresismo con la constitución estadounidense. Las representaciones del sistema político angloamericano del moderantismo variaron entre su abierta demonización y su instrumentalización en clave hispanista e

149 Tomás Bertrán Soler, Monarquía Constitucional: dedicada a los Pueblos Hispano-Americanos que quieran constituirse bajo un sistema Monárquico-Constitucional, 2a ed (Madrid: Imprenta de Sanchiz, 1842), pp. XVIII-XIX.

150 Tomás Bertrán Soler, Monarquía Constitucional: dedicada a los Pueblos Hispano-Americanos que quieran constituirse bajo un sistema Monárquico-Constitucional, op.cit., pp. 1-3.

151 Tomás Bertrán Soler, Monarquía Constitucional: dedicada a los Pueblos Hispano-Americanos que quieran constituirse bajo un sistema Monárquico-Constitucional, op.cit., pp. 38-62.

152 Tomás Bertrán Soler, Monarquia Constitucional: dedicada a los Pueblos Hispano-Americanos que quieran constituirse bajo un sistema Monárquico-Constitucional, op.cit., pp. 8-34.

153 Tomás Bertrán Soler, Monarquía Constitucional: dedicada a los Pueblos Hispano-Americanos que quieran constituirse bajo un sistema Monárquico-Constitucional, op.cit., pp. XIII-XIV. 
historicista. En todo caso, los moderados fueron tanto o más prolijos que sus homólogos exaltados a la hora de producir una gama de discursos jurídicos, historiográficos, ensayísticos, parlamentarios y docentes dedicados a articular una interpretación doctrinal sobre el constitucionalismo norteamericano.

Es necesario recordar brevemente los importantes matices históricos e ideológicos que distanciaban a los integrantes de esta cultura politica de los progresistas. Los líderes históricos que asumieron las riendas del Partido Moderado a partir de los años 30, entre los cuales destacaron figuras como Francisco Martínez de la Rosa, el Conde de Toreno y Antonio Alcalá Galiano, habían sido miembros muy activos del partido reformador durante los periodos constitucionales previos (1810-1814/1820-1823) y habian tenido roles protagónicos en las Cortes, los gabinetes y las logias masónicas que habían compuesto las redes de poder del constitucionalismo hispánico ${ }^{154}$. Estos se habían visto intimamente implicados en la gestión política de la crisis transatlántica de la Monarquía, finalizada con las independencias. Tras su paso común por el exilio en Inglaterra y Francia, se habian empapado de las corrientes ideológicas que proliferaban entre las redes intelectuales y asistenciales que les habian acogido ${ }^{155}$ : el doctrinarismo francés de François Guizot y Benjamin Constant ${ }^{156}$, el utilitarismo benthamita y el historicismo jurídico de inspiración burkeana ${ }^{157}$.

Estas líneas de pensamiento indujeron a sus líderes a renegar del pensamiento constitucional de signo revolucionario e iusnaturalista que habian profesado durante las décadas previas, conduciéndoles a la búsqueda de nuevos lenguajes y valores que debian permitir conciliar ciertos principios axiales del liberalismo con un orden contrarevolucionario respetuoso de la propiedad y la prerrogativa real, fundamentado en la diferenciación entre unos derechos civiles universalizados y unos derechos políticos limitados a la élite económica e intelectual ${ }^{158}$. Estos "conversos" habian retornado a España decididos a tomar las riendas del poder politico que les ofrecía la regente María Cristina a cambio de su apoyo ante el antiliberalismo militante de Don Carlos ${ }^{159}$. Tras un período de relativa hegemonía con la aprobación del Estatuto Real de 1834, el Partido Moderado se alineó con la regente contra el poder en aumento del progresismo, entre 1836 y 1843. Después del pronunciamiento contra Espartero de 1843, y

154 Ver: Antonio Alcalá Galiano, Memorias de D. Antonio Alcalá Galiano, publicadas por su hijo, Impr. de E. Rubiños, Madrid, 1886, http://archive.org/details/memoriasdedanton01alca.

155 Daniel Muñoz Sempere y Gregorio Alonso García, Londres y el liberalismo hispánico, Iberoamericana, Madrid, 2011.

156 Para comprender el pensamiento doctrinario: Ramón Punset Blanco, "Guizot y la legitimidad del poder", Historia constitucional: Revista Electrónica de Historia Constitucional, $\mathrm{n}^{\circ}$ 10, 2009, pp. 455-463; Lucien Jaume, "Tocqueville et Guizot: l'Amerique et l'aristocratie (une controverse)", Historia constitucional: Revista Electrónica de Historia Constitucional, n 15, 2014, pp. 71-75.

157 Sobre sus lineamientos intelectuales: Xosé Ramón Veiga, “El liberalismo conservador. Orden y libertad" en María Cruz Romeo y María Sierra (Edit.), La España liberal, 1833-1874, Marcial Pons, Madrid, 2014, pp. 289-316; Sierra Alonso, "Legisladores hereditarios", op.cit., pp. 23-50.

158 Antonio Alcalá Galiano, Lecciones de derecho politico constitucional, Imprenta de D.I. Boix, Madrid, 1843, p. 194.

159 Miguel Artola, Partidos y programas politicos, 1808-1936. I, Alianza Editorial, Madrid, 1991, pp. 218-254. 
tras la aprobación de una nueva constitución en 1845, los moderados lograron abrir una nueva década de hegemonía en que pudieron aplicar los principios de su ideario constitucional y gubernativo ${ }^{160}$. A esto se unió la consolidación y proliferación de una prensa de opinión que socializó eficazmente sus imaginarios transatlánticos, especialmente en medios como El Heraldo, El Castellano y El Español, que publicaron cuantiosas series y artículos monográficos sobre asuntos americanos.

A lo largo de las décadas que siguieron a 1834, los pensadores del moderantismo se inclinaron por imaginar a los Estados Unidos como una extensión de Gran Bretaña. Esta idea se intensificó en el contexto de la guerra librada entre el país angloamericano y México entre 1847 y 1848. La prensa moderada aprovechó el momento para disociar la legitimidad de las revoluciones de independencia en la América anglosajona y la América española. Según Carlos Retortillo, uno de los expertos americanistas del periódico "monárquicoconstitucional" El Español, la federación no era más que una "colonia" que había adquirido independencia politica y dimensiones imperiales. A pesar de las pugnas que emergian entre las dos potencias por el control de Canadá y el Caribe, los Estados Unidos, en su opinión, mantenían con la antigua metrópoli una relación de identidad lingüística, cultural e histórica y de complementariedad económica, sirviendo como exportadores de materias primas para sus industrias y como destino de su excedente poblacional. Retortillo contrastaba la prosperidad de los norteamericanos con el estado decadente que, según su opinión, habian exhibido todos los países de la América española en las décadas siguientes a su emancipación. La conquista parcial de México parecía confirmar, en su opinión, este contraste oprobioso para la "raza hispana". El desfase evidente entre ambos espacios no se explicaba, como habían denunciado los panfletos de los republicanos españoles, porque la supuesta herencia de monarquismo, catolicismo y corporativismo que había legado el imperio español estuviese entorpeciendo la realización de los proyectos constitucionales de la América del Sur. La interpretación de Retortillo era justo la opuesta. Según él, los Estados Unidos habian sabido construir su independencia en base a las tradiciones jurídicas anglosajonas y al mantenimiento e incluso el incremento de su relación con la metrópoli ${ }^{161}$.

En otros artículos comparativos, los editores de El Español defendieron que el federalismo democrático de la república angloamericana era una expresión de continuidad con su historia constitucional y politica, mientras que el mismo modelo aplicado en el mundo hispano suponía una ruptura con el rico acervo de costumbres jurídicas que había garantizado el orden público y la prosperidad de España y sus Américas durante tres largos siglos ${ }^{162}$.

Mariano Torrente, diplomático y economista de tendencias monárquicas y ultraconservadoras que se había implicado en la cruzada realista contra la

160 Fidel Gómez Ochoa, "El liberalismo conservador español del siglo XIX: la forja de una identidad politica, 1810-1840", Historia y politica: Ideas, procesos y movimientos sociales, $\mathrm{n}^{\circ} 17$, 2007, pp. 37-68.

161 C Retortillo, "Revista Politico-Diplomática”, El Español, 28 de diciembre de 1847, p. 2.

162 “Correspondencia Estranjera”, El Español, 4 de julio de 1846. 
independencia de la América Española ${ }^{163}$, había construido ya una interpretación similar. A finales de los años 20 habia publicado uno de los textos más relevantes a la hora de definir la interpretación que el hispanismo conservador haría de las emancipaciones ultramarinas: Historia de la Revolución Hispano-Americana. Según Torrente, la emancipación de los Estados Unidos había sido el opuesto a las independencias de las repúblicas del sur: si una habia sido consecuente con las tradiciones jurídicas de su "Madre Patria", las otras se habian realizado sobre una burda imitación del constitucionalismo estadounidense. Esto había supuesto el rechazo a las normas consuetudinarias que articulaban sus sociedades, desintegrándolas a la vez que provocaba una ruptura trágica con España. Torrente recurría a una caracterización dicotómica de las sociedades coloniales de la América hispanohablante y la América angloparlante, justificando así la necesidad de que los sistemas normativos que las regulasen estuviesen fundados en principios antagónicos. Torrente representaba a las Trece colonias como sociedades de ascendencia europea y relativamente homogéneas, educadas en los valores del trabajo y la ética protestante y provistas de una tradición de asamblearismo popular que las predisponía para asumir la independencia politica:

\begin{abstract}
"Todavía se ofrecen al profundo observador razones que no son de peso inferior para persuadir de que las mismas causas que hicieron perder la Inglaterra sus dominios ultramarinos, deberian haber conservado los españoles, i en el dia contribuir á su recobro. Los Estados Unidos se componian de gentes de todas naciones de Europa, ligadas por intereses de comercio i por su propia conservación: los indígenas eran pocos i Vivian sin civilización i sin roce alguno con los colonos. Esta asociación de hombres, si bien nueva i compuesta de elementos diversos, era una en su esencia, é indivisible en sus sentimientos de mirar por el fomento de sus intereses, emancipándose de un poder estrangero cual reconocían en toda la acepción de la palabra al de Inglaterra. Independientemente de este estímulo simultáneo, todo estaba alli preparado para la separación: luces, instrucción, laboriosidad, industria, comercio, población, espíritu público, estados parciales, asambleas populares, i reglamentos constitucionales; solo faltaba dar el impulso, hacer la facil mudanza de que el Presidente del Estado fuera americano en vez de inglés"164.
\end{abstract}

Por el contrario, las sociedades de la América española eran caracterizadas como compuestos étnicamente heterogéneos. En su opinión, la abundancia de poblaciones indigenas, africanas y mestizas y la diversidad de intereses y de poderes que era consustancial a la misma, requería de la perpetuación del marco policéntrico de jurisdicciones y corporaciones que habian sancionado las Leyes de Indias. Este dependía, a su vez, del supremo arbitrio de la Corona y del poder aglutinante de la Iglesia Católica ${ }^{165}$. Torrente concluía que, movidas por sus intereses elitistas, las minorias "criollas" habían impulsado el proceso independentista. Para ello habian adoptado los modelos extraños del

163 Durante los años 30, sin embargo, sabría reciclarse, sirviendo a varios gobiernos moderados como agente experto en materias ultramarinas, siendo nombrado Intendente de la Habana.

164 Mariano Torrente, Historia de la Revolución Hispano-Americana, vol. I, op.cit., pp. 65-66.

165 Mariano Torrente, Historia de la Revolución Hispano-Americana, vol. I, op.cit., pp. 66-68. 
constitucionalismo francés y estadounidense, sin percatarse de que estos no guardaban correspondencia con las condiciones objetivas de las sociedades que pretendian regir ${ }^{166}$. El republicanismo y la sanción de derechos ciudadanos igualadores, auguraba Torrente, provocaría la total rebelión de las "castas" que poblaban las Américas. Estas, libres de la autoridad centralizadora de la Corona y de la influencia moderadora del culto católico, se arrojarian, en opinión del publicista conservador, a una lucha desenfrenada por el poder que tendría como resultado la anomia legal, la división territorial y el desorden público perenne ${ }^{167}$.

Por supuesto, esta lectura de las independencias ultramarinas tenía el claro objetivo de legitimar las aspiraciones de reconquista que albergaron las administraciones del absolutismo durante la década de los años 20168. No obstante, Torrente reafirmó en buen grado estas representaciones en sus escritos de las décadas subsiguientes, reiterando que las sociedades étnicamente diversas de la América española eran incompatibles con el modelo federal y democrático de los Estados Unidos, precisando de formas monárquicas y consuetudinarias de legalidad ${ }^{169}$. Torrente reiteraría más adelante esta visión para defender los grandes proyectos geoestratégicos que guiaron la politica americana de los gabinetes de la Década Moderada (1844-1854): la contención de la influencia estadounidense en Cuba y Puerto Rico; la reincorporación de Santo Domingo al imperio español; y la creación de monarquías constitucionales en México y Sudamérica ${ }^{170}$. De cualquier modo, la obra de Torrente dejaba bien establecido un axioma del hispanismo conservador: la vinculación del constitucionalismo estadounidense con las tradiciones y usos sociales específicos de los pueblos anglosajones y su disociación de las tradiciones hispánicas.

Durante los años 40, pensadores moderados como el jurista José María Aurrecoechea ${ }^{171}$ y el escritor Jacinto Salas y Quiroga ${ }^{172}$ respaldaron a Torrente en esta interpretación historicista de la independencia norteamericana y de las instituciones derivadas de la misma. Según ambos, la rebelión de las Trece Colonias contra la Monarquia inglesa habia estado justificada en virtud de las leyes centenarias profesadas por los pueblos anglosajones. Habian sido el parlamento de Westminster y el rey de Inglaterra los que habian tratado de introducir innovaciones en el sistema fiscal, conculcando el pacto colonial que había asegurado la fidelidad de los súbditos ingleses de ultramar. La imposición unilateral de nuevos tributos sobre el té y el timbre por parte del parlamento había significado la abolición práctica de los privilegios corporativos recogidos en

166 Mariano Torrente, Historia de la Revolución Hispano-Americana, vol. I, op.cit., pp. 51-53.

167 Mariano Torrente, Historia de la Revolución Hispano-Americana, vol. I, op.cit., pp. 70/98-102.

168 Michael P Costeloe, La respuesta a la independencia: la España imperial y las Revoluciónes hispanoamericanas, 1810-1840, D.F.: FCE, México, 2011.

169 Mariano Torrente, Politica ultramarina: que abraza todos los puntos referentes a las relaciones de España con los Estados Unidos, con la Inglaterra y las Antillas, y señaladamente con la Isla de Santo Domingo, D.A. Avrial, Madrid, 1854, pp. 346-364.

170 Mariano Torrente, Politica ultramarina, op.cit., pp. 310-27.

171 José María de Aurrecoechea, Historia sucinta é imparcial de la marcha que ha seguido en sus convulsiones politicas la América Española hasta declararse independiente de su antigua metrópoli, Imprenta a cargo de D. Juan Rebollo, Madrid, 1846, pp. 25-26.

172 Jacinto de Salas y Quiroga, Historia de Inglaterra, Est. Tip. Pascual Madoz y L. Sagasti, Madrid, 1846, pp. 389-414. 
las cartas y privilegios otorgados por la Corona. Aurrecoechea y Salas aclaraban que estas constituciones locales reconocian a las asambleas coloniales la prerrogativa de controlar cualquier tipo de tasación que afectase a la economía ultramarina. Por tanto, en la retórica moderada, la Declaración de Independencia de los Estados Unidos aparecía como un acto legitimado por la legalidad colonial, mientras que la Constitución de 1787 se perfilaba como un documento funcional a las necesidades e intereses positivos de las sociedades norteamericanas. Estos diagnósticos no servían, como en la retórica de sus homólogos progresistas, para reivindicar la transferencia de ciertos principios del constitucionalismo americano a España y sus excolonias, sino para demostrar que formaban parte de una tradición en todo ajena a la historia y las necesidades de las sociedades iberoamericanas. Aurrecoechea, abogando por una intervención de las monarquias europeas contra el expansionismo estadounidense, lo expresó con claridad: "La Europa no puede dudar tampoco que la prosperidad de las colonias que fueron de la España, si á ellas se trasladan los principios del sistema de los Estados Unidos bajo el dominio de estos, deberá serla muy perjudicial"173.

También José María Queipo de Llano, Conde de Toreno, uno de los principales líderes políticos del moderantismo, abundó en esta interpretación. En su historia de las guerras napoleónicas en España, publicada en 1835, defendió que la revolución republicana de los Estados Unidos no había sido, como en Francia o las colonias españolas, un atentado contra las formas antiguas de organización legal y de gobierno. Por el contrario, había surgido como una defensa de las tradiciones legales anglosajonas y de la racionalidad histórica ante las políticas centralizadoras de Westminster:

\begin{abstract}
"Los Estados Unidos separáronse de Inglaterra en sazón en que esta descubría su frente serena y poderosa, y después que reiteradas veces les habia su metrópoli negado peticiones moderadas en un principio. Por el contrario los americanos españoles cortaban el lazo de unión, abatida la península, reconocidas ya aquellas provincias como parte integrante de la monarquía, y convidados sus habitantes á enviar diputados á las cortes"174.
\end{abstract}

El periódico moderado El Castellano respaldó en 1845 la opinión del Conde: los americanos de habla inglesa se habian rebelado contra una metrópoli que pretendia expandir su inmenso poder a costa de los derechos de sus súbditos ultramarinos. Por el contrario, los americanos españoles habian hecho la revolución contra una España hundida y necesitada mientras esta les concedía, justo en el momento de su insurrección, el enorme privilegio de participar en las Cortes de Cádiz en pie de igualdad ${ }^{175}$. José Canga-Argüelles, importante estadista que habia basculado del liberalismo radical a tendencias liberal-conservadoras, también habia denunciado en 1829 el contraste entre el noble propósito de los estadounidenses y la "negra ingratitud" de los "hermanos ultramarinos" de los

173 José María de Aurrecoechea, Historia sucinta é imparcial de la marcha que ha seguido en sus convulsiones políticas la América Española, op.cit., p. 45.

174 José María Queipo de Llano, Historia del Levantamiento, Guerra y Revolución de España, vol. III, Imp. de Don Tomás Jordán, Madrid, 1835, p. 442.

175 "Politica Estrangera", El Castellano, 14 de agosto de 1845. 
españoles ${ }^{176}$. La disociación entre el republicanismo racional, noble y fundamentado en la experiencia histórica de los angloamericanos y el republicanismo mezquino, injustificado y disociado de la realidad de los revolucionarios españoles e hispanoamericanos se situó en el tuétano de la lectura moderada del constitucionalismo angloamericano.

Francisco Martínez de la Rosa, el afamado escritor y político que ocupó en varias ocasiones la cartera de Ministro de Estado y fue miembro activo de la Real Academia de Jurisprudencia, profundizó aún más en la lectura historicista de los origenes legales de los Estados Unidos. En su obra El Espiritu del Siglo177 afirmaba que el Congreso Continental había sido, en rigor, una agrupación de repúblicas coloniales preexistentes. El lider moderado celebraba que estas, a pesar de haber adoptado los lenguajes de la Ilustración radical y del iusnaturalismo en su Declaración de Independencia ${ }^{178}$, se habian limitado en la Constitución de 1787 a sustituir el vínculo de una Corona conculcadora de derechos por el de un gobierno federal común: "La revolución americana era más bien (si cabe decirlo asî) un recobro de independencia que una conquista de libertad; pues bastaba a aquellas provincias romper la cadena que unía a otra nación, situada a millares de leguas, para hallarse constituidas en república federativa"179.También lo sostuvieron así los periodistas de El Heraldo, predicando que los ciudadanos de Norte América habían estado preparados para instituir gobiernos independientes desde el momento mismo de su desembarco:

\begin{abstract}
"al desembarcar en las playas del Norte de América llevaban imbuido en el ánimo el principio del self-government, que no han hecho más que aplicar y estender en las vastas soledades del Nuevo Mundo, convirtiendo en ciudades ricas y populosas los desiertos donde vagaban tribus salvajes" 180 .
\end{abstract}

Antonio Alcalá Galiano, otro de los líderes politico-intelectuales del moderantismo, también dedicó una buena parte de su labor docente y publicística a defender la idea de que el sistema legal de los Estados Unidos estaba arraigado en el Common Law anglosajón. Sus ideas alcanzaron concreción en las lecciones sobre derecho constitucional que impartió en el Ateneo de Madrid a principios de los años 40. Galiano, consumado pensador jurídico, les explicó a sus estudiantes que los revolucionarios norteamericanos no habian reclamado "sus derechos naturales, sino los de bretones nacidos libres, los históricos adquiridos de sus padres como ingleses, y no como criaturas humanas"181.

Precisamente por ello, los estadounidenses no habian tenido la necesidad de redactar una constitución larga y compleja como lo habían hecho los

176 José Canga Argüelles, Breve respuesta a la representación de los comerciantes de Londres, y a varios artículos depresivos del honor del monarca español, insertos en el periódico 'El Times', Sobre el reconocimiento de la independencia de las Américas Españolas, Publicado e impreso por D M Calero, Londres, 1829, p. 6.

177 Un híbrido entre ensayo filosófico, la memoria política y la historia universal que publicó entre 1835 y 1851 .

178 Francisco Martínez de la Rosa, Espíritu Del Siglo, vol. I, Baudry, Paris, 1844, pp. 86-87.

179 Francisco Martínez de la Rosa, Espíritu Del Siglo, vol. I, op.cit., pp. 87-88.

180 “Parte Politica. Madrid 2 de Noviembre," El Heraldo, 2 de noviembre de 1847.

181 Antonio Alcalá Galiano, Lecciones de derecho político constitucional, op.cit., pp. 66-67. 
constitucionalistas españoles en 1812. Los primeros, decía, solo habían precisado de definir un marco básico de convivencia en el que pudieran continuar desarrollando sus normas y formas políticas precedentes, mientras que los segundos habian tenido que reinventar todos los aspectos de la arquitectura institucional del nuevo Estado constitucional. Esta profusión normativa era la consecuencia de haber intentado partir de cero, desconociendo las tradiciones legales y formas sociales que prevalecian aún en la Monarquía ${ }^{182}$.

Así, a la crítica del republicanismo hispanoamericano se unía la crítica del propio liberalismo radical español, con el cuál Galiano identificaba a sus actuales opositores exaltados. Esta postura quedó en evidencia en su relato de la historia reciente de España. El moderado, inculpando a su propio yo juvenilis3, consideraba que aquellos que habían apoyado la Constitución de 1812 y su intento de convertir el imperio español en una comunidad planetaria de ciudadanos iguales ante la ley, habian contribuido a dinamitar los fundamentos legales que habian garantizado el orden y la unidad de las sociedades hispánicas ${ }^{184}$. En lugar de optar por una reforma progresiva, que permitiese la expansión calculada de los derechos civiles y de las libertades individuales mientras se les daba continuidad a los órdenes estamentales heredados, los revolucionarios se habian dejado llevar por las utopías destructoras de la soberania popular, sin comprender que el experimento estadounidense estaba respaldado por la tradición y no tenía nada de utópico. ${ }^{185}$

\subsection{Democracias opuestas: el constitucionalismo estadounidense y el monarquismo hispanista.}

En este contexto, Alcalá Galiano les proponía a los oyentes de sus lecciones ateneístas que la comparación entre Estados Unidos y la América española demostraba el carácter circunstancial y relativo del significante democracia. Subrayando esta inestabilidad semántica, Galiano sugirió que la democracia debía entenderse como cualquier arquitectura jurídica que mantuviese un alto nivel de adaptación y correspondencia con las costumbres de la sociedad bajo su amparo $^{186}$. Galiano afirmaba que la Monarquía española absoluta había estado intimamente unida al interés y amor de la plebe durante la Edad Moderna. Se habia correspondido con las costumbres y con la voluntad general de los pueblos bajo su seno. Por ello, era comparable a la democracia popular de la Unión angloamericana, donde la soberanía del pueblo era absoluta. Si bien podían parecer sistemas antagónicos, en ambos casos el principio de gobierno y el hecho social se correspondian: la Monarquía imperial hispana había sido fiel reflejo de sus sociedades estamentales; el Estado federal americano lo era de sus sociedades igualitarias. En ambos casos las "leyes" concordaban con las "costumbres" y en ambos casos se podia hablar de un "espíritu democrático":

182 Antonio Alcalá Galiano, Lecciones de derecho politico constitucional, op.cit., p. 415.

183 Alcalá Galiano, Historia de España, VI, Imprenta de la sociedad literaria y tipográfica, Madrid, 1846, p. 365.

184 Alcalá Galiano, Historia de España, VII, op.cit., pp. 160-62.

185 Alcalá Galiano, Historia de España, VI, op.cit., pp. 419-421.

186 Antonio Alcalá Galiano, Lecciones de derecho político constitucional, op.cit., p. 72. 
"en uno y otro pueblo, si las constituciones eran opuestas entre sí, dominaba el interés e influjo de la democracia; de la muchedumbre. Allí el presidente saca su poder de la elección del pueblo, y para él manda. Aquí el rey lo era tanto cuando su derecho, por el amor popular, y al interés de la plebe más que a otro alguno atendía. Allá la igualdad reina en la sociedad y en las leyes: aqui, a pesar de las leyes, por ser democrática la indole del gobierno, reinaba más que en otra monarquía de las de Europa, y más por cierto que en Inglaterra" 187.

Galiano no estuvo solo en esta justificación en clave democrática del Antiguo Régimen, que abundaba en la necesidad de disociación entre el constitucionalismo hispánico y anglosajón. En el mismo sentido argumentó en 1844 el abogado y diputado Luis Manuel Rivero, si cabe con un mayor deje conservador. Este había acudido dos años antes a México en un viaje profesional. $\mathrm{Su}$ contemplación directa de las inestabilidades crónicas que afectaban a la nueva república le inspiró a escribir un híbrido entre el libro de viajes y el ensayo titulado Méjico en 1842. El jurista, que poco más tarde se convertiria en el comentarista periodístico que designó el diario El Español para analizar la invasión estadounidense de México, trató de construir un concepto de democracia hispánica distanciado del sentido liberal, voluntarista e individualista que en su opinión le daban las instituciones estadounidenses ${ }^{188}$.

Según Rivero, las sociedades del imperio español de Antiguo Régimen habían sido igualitarias, pero en un sentido radicalmente opuesto al que había propuesto la Declaración de Independencia de los norteños. El pluralismo jurídico y corporativo de las sociedades hispanas había sido antitético a la homogeneidad propuesta por los regímenes ciudadanos. Sin embargo, el imperio de España había garantizado que, en un marco de diferencias estructurales en lo cultural, lo económico y lo social, se garantizase la universalidad de derechos en el amparo proporcionado por las leyes civiles de la Monarquía y en el acceso al aparato asistencial de la Iglesia. Así, la sociedad indiana había tenido una organización en "su fondo democrática, dominada como estaba por el sentimiento religioso y por el de igualdad civil"189. Los reyes y su suprema jurisdicción, y no los recuerdos arcanos del constitucionalismo medieval, ni los derechos naturales, habian sido los ámbitos unificadores e igualadores. El viajero, como Galiano, aprovechaba la inestabilidad semántica del concepto de democracia, desvinculándolo de su asociación a las prácticas electorales o a la libertad individual y significándolo como un sistema que garantizaba la igualdad social a través del poder tutelar del trono y del altar.

En un artículo llamado "El Fin y los Medios" el periódico “joco-serio" La Posdata defendía una idea similar a las de Galiano y Rivero. Las experiencias recientes de las Américas demostraban, en opinión de sus editores, que la libertad politica no se podia entender como un fin en sí mismo y menos cuando su aplicación iba contra la libertad civil, la seguridad individual y la tranquilidad

187 Antonio Alcalá Galiano, Lecciones de derecho político constitucional, op.cit., pp. 45-46.

188 Luis Manuel Rivero, “Guerra de Méjico. Artículo II”, El Español, 10 de noviembre de 1847.

189 Luis Manuel del Rivero, Méjico en 1842, Imprenta y Fundicion de D.E. Aguado, Madrid, 1844 , p. 30. 
y el bienestar general. En las repúblicas "Iberoamericanas" había sido incompatible con la prosperidad y la grandeza, mientras en EE. UU. la había potenciado. Prusia, por su parte, no tenía libertad politica y era grande, feliz y poderosa. Los hombres que se morian de hambre en el mundo hispanohablante no debían disputar sobre derechos políticos y, en su caso, lo más "democrático" era un régimen autoritario ${ }^{190}$.

El ejercicio de historización de la democracia americana y su denostación como modelo aplicable al constitucionalismo hispánico, servía a los pensadores del conservadurismo para deslegitimar los experimentos republicanos en la América española. Para ello debían subrayar los elementos sociopolíticos que permitian el buen funcionamiento de las leyes angloamericanas. Rivero, que ya había sido precedido en estas apreciaciones por Torrente, observaba que la Unión del Norte no era otra cosa que una agrupación de colonias compuestas de todas las "naciones de Europa". Sin embargo, estaban ligadas por la cultura politicoreligiosa, puritana y democrática que se habia cimentado desde los primeros colonos. A esto se unían los intereses del comercio, el poder aglutinante que tenía el reparto sin límites de propiedades y la consiguiente consistencia histórica del proyecto político y territorial de la Unión, que además aseguraba la homogeneidad con la eliminación de los elementos indígenas ${ }^{191}$.

Galiano, por su parte, celebró el hecho de que la federación angloamericana se hubiese formado en base a las tradiciones sajonas y normandas. Dictaminó que esto había facilitado que se conservase el sentido de la honorabilidad de los antepasados y que se hubiera podido articular sobre esa base una fidelidad al Estado similar a la que existía en los regimenes monárquicos ${ }^{192}$. Así lo hacía notar también el editor de la Revista de España y el Estrangero, Fermín Gonzalo Morón, publicista de tendencias conservadoras que se erigió en uno de los grandes soportes del moderantismo. Según este prolífico escritor, el "estímulo simultáneo" que había llevado la revolución liberal a todos los rincones del Atlántico había encontrado a las colonias continentales de Inglaterra preparadas para su separación en todos los niveles: con asambleas populares bien constituidas, reglamentos constitucionales, industria, comercio, "instrucción" y "espíritu público", y con los "Estados parciales" que ya eran las colonias. En las posesiones españolas faltaban, en su opinión, todos estos elementos: sin unión entre clases, sin un centro común de fidelidad ajeno a la Corona, con una numerosa población indigena y africana y sin un patriotismo alternativo a la adscripción imperial193.

En general, triunfó una visión netamente historicista del proceso de formación de la legalidad estadounidense. Dicha visión se afirmaba en la idea toquevilliana de que la democracia popular sancionada por la Constitución estadounidense de 1787 no era el resultado de un mero proyecto filosófico, sino la enunciación de un hecho consumado en las prácticas de democracia local que

190 "El Fin y Los Medios", La Posdata. Periódico Joco-Serio, 8 de enero de 1842, 4.

191 Luis Manuel Rivero, “Guerra de Méjico. Artículo II”, El Español, 10 de noviembre de 1847.

192 Antonio Alcalá Galiano, Lecciones de derecho politico constitucional, op.cit., pp. 29-30.

193 Fermín Gonzalo Morón, "Gobierno y costumbres de los Estados Unidos. Reseña y juicio de la obra 'De la Democracia en América por Ms. Alexis de Tocqueville'. Examen de los bienes y males de la democracia. Artículo 10", Revista de España y del Estrangero, n I, 1842, pp. 20-21. 
habían desarrollado las asambleas y sociedades de cada colonia desde su fundación. De ahí que pensadores como el monárquico irlandés George Dawson Flinter, fidelizado con el absolutismo español durante las guerras de independencia ${ }^{194}$, afirmasen que Estados Unidos era la única república del planeta que se basaba en un proyecto racional, realizable y radicado en la experiencia histórica ${ }^{195}$. Rivero también defendió que en la rebelión de las colonias inglesas habia brillado la cordura. De hecho, comparaba esta con el mitificado levantamiento de España contra Napoleón: en ambos casos se abrazaban la "fuerza y el derecho". En la revolución mejicana de independencia, por el contrario, "nada había de digno, grande o justificado, siendo las proclamas del congreso mejicano de 1815 una colección de falacias políticas" contra el dominio hispano ${ }^{196}$.

Francisco Martínez de la Rosa defendió, en esta línea, que los sectores progresistas de España y sus excolonias se habian aplicado a un ejercicio sistemático de descontextualización del ejemplo estadounidense, ignorando las claras orientaciones conservadoras de su institucionalidad $\mathrm{y}$ tomando exclusivamente las proclamas demagógicas de las "sociedades populares". El éxito de la independencia estadounidense demostraba para el jurista, que, en las naciones acostumbradas a la libertad racional sancionada por la propiedad y el orden, como las anglosajonas, las intentonas revolucionarias radicales estaban condenadas al fracaso ${ }^{197}$.

Esta afirmación de Martínez se encuadraba en la tendencia que él y otros intelectuales conservadores tuvieron a alabar el carácter moderado que le habian dado los lideres del partido federalista americano a las instituciones de la república. El ministro insistió en que los postulados más conservadores del partido federal de Washington, Adams, Jay y Madison se habían impuesto a los postulados más democráticos de Jefferson durante el proceso constituyente. Esto se había traducido en el establecimiento de un sistema bicameral, que privilegiaba la limitación del brazo popular, les daba poder a las élites del sur, y alimentaba la capacidad de arbitrio de la presidencia. Estados Unidos les había mostrado el camino del bicameralismo a la mayoria de los Estados liberales del mundo euroamericano (destacaba a Francia, Holanda, Bélgica, España, Brasil e incluso Haitî), que habían tenido que limitar la excesiva democratización que suponia el unicameralismo, creando altas cámaras de representación corporativa o territorial ${ }^{198}$.

El Conde de Toreno, que también mostró su admiración por Adams y el resto de los ideólogos federalistas, reivindicó la importancia que habían tenido los

194 George Dawson Flinter, A History of the Revolution of Caracas: Comprising an Impartial Narrative of the Atrocities Committed by the Contending Parties, sold by Bell \& Bradfute; W. Gribben, Edinburgh; Dublin, 1819.

195 George Dawson Flinter, Examen del estado actual de los esclavos en la isla de Puerto Rico bajo el gobierno español: en que se manifiesta la impolitica y peligro de la prematura emancipación de los esclavos en la India Occidental, Imprenta Española del Redactor, Nueva York, 1832, p. 68.

196 Luis Manuel del Rivero, Méjico en 1842, op.cit.,pp. 49-52.

197 Francisco Martínez de la Rosa, Espiritu del Siglo, vol. I, op.cit., p. 101.

198 Francisco Martínez de la Rosa, Espíritu del Siglo, vol. I, op.cit., pp. 157-163; Francisco Martinez de la Rosa, Espíritu del Siglo, vol. II, op.cit., p. 5; Francisco Martínez de la Rosa, Espíritu del Siglo, vol. III, op.cit., p. 197. 
Estados Unidos en la discusión que las Cortes de Cádiz habían sostenido sobre las leyes fundamentales de la Monarquía. La federación, narraba, había sido citada como modelo de gobierno democrático operativo, y en muchos casos había servido para sostener teorías moderadas, como la necesidad de una cámara alta, el fortalecimiento del ejecutivo o la limitación de los derechos políticos a los descendientes de africanos ${ }^{199}$. De hecho, Toreno parecía encontrar en la legislación americana un modelo funcional al régimen esclavista que estableció el Estado español decimonónico en Cuba y Puerto Rico ${ }^{200}$. El Conde, citando los discursos que habían defendido la exclusión ciudadana de los africanos en las Cortes de Cádiz ${ }^{201}$, se posicionaba en favor de los regímenes de excepcionalidad que la república les aplicaba a las poblaciones indigenas y, sobre todo, a los esclavos $^{202}$.

El énfasis que hacía Toreno en los elementos conservadores de la Constitución de 1787 se revelaba como un poderoso recurso argumentativo para subrayar el carácter utópico y radical de algunos elementos esenciales de la agenda exaltada y republicana, como lo eran el unicameralismo y el sufragio universal. Toreno adelantaba en su escrito, publicado en 1835, algunos de los argumentos que esgrimiría su partido para justificar la consagración en la Constitución de 1845 del voto censitario y la concesión de un peso institucional elevado al Senado, que actuaba como Cámara Alta garante de la representación corporativa ${ }^{203}$.

José de Aurrecoechea también alababa a los artífices intelectuales del constitucionalismo americano, subrayando su altura filosófica frente a demagogos filodemocráticos del mundo hispánico. Los legisladores estadounidenses aparecían como héroes gubernativos que habían sabido plasmar constitucionalmente los anhelos del pueblo norteamericano, mientras los republicanos del mundo hispánico aparecían como sus torpes imitadores:

"Las principales colonias del Norte-América recibieron las primeras leyes de los filósofos mas célebres y mas virtuosos de aquellos tiempos. Guillermo Penn fundó la Pensilvania á sus espensas: Locke, tan célebre en la historia, fué el legislador de la Carolina; y ambos establecieron pacíficamente los principios que habian costado á la Europa torrentes de sangre. Hablemos con imparcialidad; ¿son comparables á los sabios Penn y Loke, los nuevos legisladores de las posesiones españolas de la América? (...) Por esto solo

199 José María Queipo de Llano, Historia Del Levantamiento, Guerra y Revolución de España, vol. IV, op.cit., p. 371.

200 Josep Maria Fradera, La Nación Imperial: Derechos, Representación y Ciudadania en los imperios de Gran Bretaña, Francia, España y Estados Unidos (1750-1918), Edhasa, Barcelona, 2015.

201 Ver: Carlos Petit Calvo, "Negros y mulatos. Españoles de ambos hemisferios", Historia constitucional: Revista Electrónica de Historia Constitucional, n 15, 2014, pp. 156-204.

202 José María Queipo de Llano, Historia Del Levantamiento, Guerra y Revolución de España, vol. IV, op.cit., pp. 355-356.

203 Javier Pérez Núñez, "La propuesta de monarquía limitada del conservadurismo autoritario durante el reinado isabelino", Historia constitucional: Revista Electrónica de Historia Constitucional, $\mathrm{n}^{\circ} 18,2017$, pp. 367-371. 
recomendaremos á nuestros federalistas, mediten sobre la distancia considerable que hay realmente entre los principios de uno y otro país"204.

Todos los testimonios aquí aludidos demuestran el esfuerzo que hicieron los moderados por apropiarse del espejo constitucional norteamericano con dos fines: subrayar la deseabilidad de los elementos conservadores de su sistema político (bicameralismo, esclavitud, voto restrictivo) a España y la América española y, al mismo tiempo, defender que su vía hacia la democracia liberal era radicalmente distinta a la que debian tomar, por su diferente constitución histórica, los países hispanohablantes.

A pesar de estas interesantes y copiosas muestras de admiración de los moderados hacia la república angloamericana, el hecho de que la Unión se convirtiera en el símbolo más visible de la democracia popular en el globo hizo que las críticas a su arquitectura jurídica proliferasen en el pensamiento conservador. Para los editores de El Heraldo, la "vana pretensión de la constitución americana de hacer iguales a todos los hombres" era el opuesto a los esquemas racionales de gobernanza basados en la experiencia histórica que proponían responsablemente las élites conservadoras del orbe hispánico. En el contexto en el que estas actuaban era necesario hacer valer las desigualdades de los sistemas consuetudinarios, jurisdiccionales y verticales del Antiguo Régimen cuando estos fueran funcionales al gobierno de los pueblos, al orden y al respeto por la propiedad ${ }^{205}$. En sus comentarios respectivos de Tocqueville, Galiano y Morón reconocían que en los Estados Unidos habia sido posible asegurar la vigencia normalizada de las leyes democráticas. Pero aclaraban que eso no aseguraba la aplicabilidad universal de sus doctrinas constitucionales, ni que estas fueran a ampliarse en el futuro a Europa ni al resto de las Américas ${ }^{206}$.

Muy al contrario, los moderados se erigieron en adalides de la monarquía constitucional en Europa y América. De hecho, decepcionados con los parcos resultados que había traído el acercamiento diplomático entre España y las repúblicas hispanoamericanas tras el reconocimiento de 1836 , los moderados se instalaron en la creencia de que la única vía posible para la construcción de un bloque panhispánico postimperial era la paulatina transformación de estos estados en monarquias constitucionales con ejecutivos fuertes. Esta creencia se acentuó en la medida en que los Estados Unidos expandian su influencia por el continente, anexándose Texas (1844) y expandiendo su esfera de influencia en el Caribe y el Pacífico. Este contexto geopolítico provocó un boom de publicaciones que comenzaron a vincular la regeneración imperial de España, la seguridad de Cuba y Puerto Rico y la supervivencia de los pueblos hispánicos en una transición monárquica de las excolonias. La Historia Sucinta é imparcial de la marcha que ha seguido en sus convulsiones politicas la América Española, publicada en 1846, de José de Aurrecoechea fue paradigmática en este sentido:

204 José María de Aurrecoechea, Historia sucinta é imparcial de la marcha que ha seguido en sus convulsiones políticas la América Española, op.cit., p. 26.

205 “Estudios Políticos. La Inglaterra en los últimos tiempos”, El Heraldo, 12 de abril de 1846.

206 Fermín Gonzalo Morón, "Gobierno y costumbres de los Estados Unidos. Reseña y juicio de la obra 'De la Democracia en América por Ms. Alexis de Tocqueville'. Examen de los bienes y males de la democracia. Artículo 2o", op. cit., pp. 72-87; Antonio Alcalá Galiano, Lecciones de derecho politico constitucional, op.cit., p. 75. 
un panfleto que afirmaba que la debilidad de México frente a los Estados Unidos se debía precisamente a que habia tratado de adoptar el modelo federal y democráticos de estos. Al contrario, decía el jurista, las sociedades hispánicas debían tomar conciencia de que su progreso politico solo podría fundarse en las tradiciones autóctonas y en el legado del monarquismo ilustrado de los borbones. Aurrecoechea abogaba por que los servicios exteriores del moderantismo español, apoyados por Francia y Gran Bretaña, promocionasen la creación de Estados monárquicos en los cuales la Corona ejerciese como un poderoso ejecutivo centralizado que direccionase los progresos sociales, tecnológicos y económicos desde el paradigma de un reformismo tutelado ${ }^{207}$.

Este imaginario geopolítico asociaba el bienestar del mundo hispánico al rechazo al constitucionalismo norteamericano, a la fidelidad al acervo políticojurídico de la monarquía imperial española y a la incorporación de las fórmulas de centralización del poder ejecutivo y expansión de la administración legadas por el doctrinarismo. Estas visiones llegaron incluso a motivar la promoción de conspiraciones monárquicas por parte de los gobiernos moderados en México, si bien estas resultaron en un profundo fracaso ${ }^{208}$. Con todo, la idea de la imitación del sistema legal norteamericano como una amenaza para el orden público, e incluso para la existencia de los estados hispánicos, quedó instalada en el pensamiento del conservadurismo español.

En esta línea, los redactores de El Español afirmaron en 1845 que el buen funcionamiento de la democracia estadounidense era una realidad circunstancial y coyuntural, que dependía, sobre todo, de la dispersión poblacional, de la disponibilidad de tierras, de la igualdad de oportunidades económicas y de la ausencia de enemigos poderosos en sus fronteras ${ }^{209}$. Fermín Gonzalo Morón defendió que, una vez se agotasen las posibilidades de expansión y se concentrasen las sociedades, las jerarquías emergerían y la civilización engendraría una élite culta. El escritor preveía que en este momento las clases populares comenzarían a reclamar mejoras en su condición y una estructura estatal necesariamente más pesada ${ }^{210}$. Estos procesos tendrian el potencial de provocar una transformación autoritaria del sistema legal, reforzando la figura del ejecutivo, debilitando los tribunales populares y los parlamentos y llevando al país a formas pseudo-monárquicas o, en caso contrario, a la fragmentación territorial en una serie de pequeñas repúblicas ${ }^{211}$. Los periódicos conservadores

207 José María de Aurrecoechea, Historia sucinta é imparcial de la marcha que ha seguido en sus convulsiones politicas la América Española, op.cit., pp. 23-48.

208 Ver: Salvador Bermúdez de Castro, Correspondencia diplomática de Salvador Bermúdez de Castro, ministro de España en México, ed. Raúl Figueroa Esquer, D.F: Instituto Tecnológico Autónomo de México Instituto Nacional de Estudios Históricos de las Revoluciónes de México, 2013.

209 "Estudios Políticos. Introducción al conocimiento del estado moral, político y económico de los Estados Americanos. Los Estados Unidos de América. Artículo II", El Español, 30 de noviembre de1845.

210 Fermín Gonzalo Morón, "Gobierno y costumbres de los Estados Unidos. Reseña y juicio de la obra 'De la Democracia en América por Ms. Alexis de Tocqueville'. Examen de los bienes y males de la democracia. Articulo 10", op. cit., pp. 17-28.

211 Fermin Gonzalo Morón, "Gobierno y costumbres de los Estados Unidos. Reseña y juicio de la obra 'De la Democracia en América por Ms. Alexis de Tocqueville'. Examen de los bienes y males de la democracia. Artículo 20", Revista de España y del Estrangero, n I, 1842, op. cit., pp. 81-82. 
se complacian en afirmar que las tensiones entre los Estados esclavistas y más aristocráticos del sur y los democráticos del norte serian el primer detonante de este proceso de descomposición ${ }^{212}$.

Más allá de las prospecciones desfavorables, Galiano y Morón emplearon la representación de la historia reciente de la federación para articular una ácida crítica de la democracia popular. Ambos subrayaban cómo la progresiva pérdida de poder de los federalistas en favor del partido democrático había ido acercando el funcionamiento efectivo del país a una "tiranía de la mayoria", en que las escasas élites cultas vivian sometidas a la voluntad del vulgo y al poder cada vez más omnímodo de la prensa de opinión ${ }^{213}$. La Unión se había convertido en el imperio de la mediocridad y, como diagnosticaba Tocqueville, se daba la paradoja de que la sociedad civil castigaba con mayor severidad las disidencias intelectuales que cualquier gobierno absoluto ${ }^{214}$. El mundo democrático era, para Morón, un "tumulto universal" un "choque repetido de intereses contrarios"215.

Las representaciones peyorativas se hicieron extensivas al modelo federal. En su defensa del centralismo de inspiración napoleónica y doctrinaria como forma de articulación territorial idónea para el Estado liberal, los medios y pensadores adeptos al Partido Moderado previeron la pronta fragmentación del espacio soberano de la federación. Los escritos de Fermín Gonzalo Morón ${ }^{216}$ y de los editores de El Constitucional 217 previeron en los años 40 que los intereses seccionales del sur esclavista y el norte industrialista terminarian por llevar a la federación a un conflicto civil que terminaría por fragmentarla en un mosaico de pequeños gobiernos republicanos. En su opinión, la amplísima autonomía que la Constitución de 1787 le garantizaba a los Estados federados y a los municipios solo podia redundar en la impotencia de los poderes centrales y en anarquía política. Así lo defendian también los editores de El Español, según los cuales si los componentes de la federación habian permanecido unidos por tantas décadas había sido por factores meramente coyunturales, como el aislamiento geoestratégico 218 .

En línea con estas críticas, otros discursos de la coyuntura dejaron en evidencia las limitaciones prácticas del modelo democrático estadounidense. En 1841 los editores de El Constitucional de Barcelona representaron a una corriente

212 “Boletín Estrangero", El Heraldo, 19 de abril de 1844; "Estados Unidos”, La Esperanza. Periódico Monárquico, September 27, 1848, sec. Noticias Estrangeras.

213 Antonio Alcalá Galiano, Lecciones de derecho político constitucional, op.cit., pp. 111-112.

214 Fermín Gonzalo Morón, "Gobierno y costumbres de los Estados Unidos. Reseña y juicio de la obra 'De la Democracia en América por Ms. Alexis de Tocqueville'. Examen de los bienes y males de la democracia. Artículo 10", op. cit., p. 27.

215 Fermín Gonzalo Morón, "Gobierno y costumbres de los Estados Unidos. Reseña y juicio de la obra 'De la Democracia en América por Ms. Alexis de Tocqueville'. Examen de los bienes y males de la democracia. Articulo 2o", op. cit., pp. 73-74.

216 Fermin Gonzalo Morón, "Gobierno y costumbres de los Estados Unidos. Reseña y juicio de la obra 'De la Democracia en América por Ms. Alexis de Tocqueville'. Examen de los bienes y males de la democracia. Articulo 10", op. cit., pp. 20-21.

217 “Del Gobierno y de los partidos estremos”, El Constitucional, 12 de enero de 1841, 2.

218 "Estudios Políticos. Introducción al conocimiento del estado moral, político y económico de los Estados Americanos. Los Estados Unidos de América. Artículo II", El Español, 30 de noviembre de 1845 . 
que trató de explicitar las limitaciones democráticas del experimento político norteamericano, subrayando la exclusión de los africanos del marco ciudadano y la no contemplación de la asimilación de los indígenas: "La libertad americana es tan parsimoniosa en sus beneficios que no se estiende más que sobre el hombre blanco"219. En esto les secundó ocasionalmente la Gaceta de Madrid, la cual reprodujo los escritos del economista político suizo Sismondi. Éste denunciaba que, a pesar de que algunas constituciones de los Estados federados le daban el voto a los "negros" y los "hombres rojos", su exclusión social impedía en la práctica que pudieran ejercer sus derechos políticos o siquiera civiles ${ }^{220}$. La imagen de la democracia estadounidense se alejaba de su tinte de idealidad para presentarse simplemente como una forma novedosa de organizar un sistema de exclusiones y privilegios no tan alejado de los del Antiguo Régimen. Sin embargo, estas críticas puntuales no permiten cuestionar el filoamericanismo generalizado que proliferó pensamiento legal del progresismo y el republicanismo español.

Los editores de La Gaceta también se aplicaron a representar las elecciones estadounidenses como un espectáculo de demagogia, violencia y anarquía. En el desarrollo de procesos electorales, contaban, los votantes pugnaban para imponerse por la fuerza de la mayoria y los candidatos no dudaban en rebajar el tono y el contenido de sus discursos con tal de contentar a la turba. Los redactores previeron que las crisis políticas y la polarización electoral que comenzaban a ser apreciables terminarian por dinamitar los cimientos jurídicos de la Unión ${ }^{221}$.

\section{IV.CONCLUSIÓN}

Las culturas constitucionales del progresismo y el moderantismo no pudieron permanecer ajenas al experimento jurídico-politico que representaban los Estados Unidos. El éxito y la durabilidad de la arquitectura institucional de la república ultramarina no tuvo, sin embargo, impactos simples ni unilineales. Los pensadores que integraron estas dos grandes corrientes del liberalismo postrevolucionario exhibieron todo un haz de posturas interpretativas que bascularon entre la admiración y el más absoluto rechazo a los postulados democráticos y federales de la Unión. Sus estrategias de lectura, traducción e interpretación del corpus textual que componía el entramado jurídico de la federación angloamericana dependieron de los objetivos concretos que cada cultura politica se fijó en el contexto de incertidumbres y desafios que planteaba la vertebración del sistema constitucional de la Monarquía tras su hundimiento con motivo de las revoluciones atlánticas (1808-1824). No existió un relato cerrado sobre la historia constitucional de los Estados Unidos, sino un duelo argumentativo para definir su significado en relación con toda una serie de conceptos jurídico-políticos que se volvieron fundamentales en la modernidad española, tales como democracia, soberanía popular, elecciones, derechos políticos, república y federación.

219 “Los Estados Unidos y sus habitantes", El Constitucional 5 de noviembre de 1841, p. 2.

220 "Concluye el artículo sobre el sufragio universal tomado de la Revista de Economía Política de Sismondi”, La Gaceta de Madrid 1 de septiembre de 1837, pp. 3-4.

221 “Estados Unidos. Elecciones”, La Gaceta de Madrid, 20 de julio de 1840. 
Así, el constitucionalismo americano influyó en varios aspectos muy concretos del debate público español. En primer lugar, funcionó como un recurso empírico obligado: proporcionó una rica casuística para legitimar o condenar ciertas formas jurídicas que no habían tenido precedentes en la historia del mundo euroamericano. Esta función se unió íntimamente a su uso orientativo como catalizador de nuevas formas de razonamiento constitucional. El desarrollo de los Estados Unidos provocó que fenómenos como el republicanismo, el federalismo y el constitucionalismo democrático se consolidasen como horizontes de posibilidad, alterando de raíz los lenguajes e imaginarios jurídico-políticos. Las experiencias constitucionales venidas del suelo de la república obligaron a los pensadores españoles a pronunciarse a favor o en contra de las mismas. Este fenómeno, palpable en el conjunto de discursos abordados, amplió el rango de escenarios constitucionales que las élites decimonónicas imaginaron para el futuro del Estado español.

La naturaleza interactiva y adaptativa de los procesos decimonónicos de circulación de modelos constitucionales ha quedado patente en el artículo. Este hecho se aprecia al evaluar el modo en que los discursos en torno al sistema normativo de la federación se convirtieron en una fuente de legitimidad para los grupos abordados. Los procesos de selección, mediación y apropiación del acervo constitucional estadounidense que progresistas y moderados llevaron a cabo estuvieron dirigidos a justificar sus respectivos proyectos politicos, como se ha evidenciado a lo largo de los apartados anteriores. Así, más que una hermenéutica metódica y academicista del corpus textual del constitucionalismo estadounidense, lo que predominó fueron dinámicas de lectura politizada, que tendieron a resaltar los aspectos de sus articulados y doctrinas más convenientes al contexto argumentativo y a las intenciones de los intérpretes progresistas y moderados respectivamente.

Los progresistas convirtieron el ejemplo americano en una fuente de legitimidad para su defensa del parlamentarismo y el municipalismo. De ahí que en el contexto de movilización y debate constituyente abierto a partir de 1834 encabezasen el "constitucionalismo de imprenta" que tradujo y editó textos fundamentales para socializar una imagen positiva del constitucionalismo estadounidense. En los paratextos que acompañaron ediciones, reseñas y traducciones este fue asociado al legado de libertad de la Constitución de 1812 y fue presentado como un repositorio inspiracional para el reformismo legal del liberalismo avanzado. Los pensadores exaltados de los años 30 y 40 fueron conscientes de que sus propuestas reformadoras rompian con el sistema jurisdiccional y corporativo que había operado secularmente en la Monarquía española. De manera cotidiana debían hacer frente al argumentario de los sectores moderados y absolutistas, que afirmaban que el quiebre radical con las tradiciones jurídicas del Antiguo Régimen solo podía conducir a la desintegración del Estado y a la anomia normativa. Las experiencias domésticas a las que los progresistas podian apelar para defender la vinculación entre el orden público y el constitucionalismo eran pocas: desde el experimento de la Constitución de 1812 la historia de la Monarquía había consistido en una sucesión ininterrumpida de revoluciones, reacciones y guerras civiles. La misma impresión dejaban en la opinión pública española las noticias llegadas de las nuevas repúblicas de Hispanoamérica que, sobre todo a partir de los años 40, parecían 
haber entrado en una espiral de militarismo, inestabilidad y fragmentación territorial.

Las únicas experiencias de constitucionalismo liberal que parecian haber cristalizado en una institucionalidad normalizada eran las del Reino Unido y los Estados Unidos. Si el sistema inglés de monarquia constitucional fue un espejo esencial para que los exaltados imaginasen las posibles formas de un modelo parlamentario hispánico, los Estados Unidos también tuvieron su lugar. La mitologización de sus experiencias de desarrollo constitucional sirvió para ofrecerle a las escépticas audiencias hispanas un ejemplo exitoso de democracia federal y representativa. La apelación a las instituciones americanas permitía construir la expectativa de que el quiebre con las tradiciones antiguoregimentales permitiria la realización de un sistema parlamentario viable, asociado no solo a los valores de la libertad personal y de conciencia, la autonomía municipal y la soberanía popular, sino también al imperio de la ley y del orden.

No obstante, se ha reflejado que la apropiación progresista del modelo estadounidense, a diferencia de la realizada por los exponentes del republicanismo, fue altamente restrictiva y selectiva. Bajo el discurso historicista de la especificidad de las tradiciones constitucionales hispánicas, los exaltados se guardaron de recomendar la importación integral del modelo estadounidense. Sus alabanzas de la democracia popular ultramarina se vieron matizadas por la idea de que los pueblos de España e Hispanoamérica aún precisaban de la tutela monárquica y del voto capacitario como garantías del orden público. De forma que la Constitución de 1787 sirvió más para defender el parlamentarismo monárquico heredado parcialmente de las Cortes de Cádiz, que cualquier proyecto de revolución republicana o democrática. Del mismo modo, la reivindicación del federalismo estadunidense se dirigió a reivindicar la agenda descentralizadora del municipalismo, sin plantear nunca la repartición de atribuciones soberanas que habria supuesto su adopción integral.

Los moderados, por su parte, apelaron a una lectura netamente historicista del constitucionalismo estadounidense, interpretándolo como un desarrollo concreto de las tradiciones jurídico-politicas de Inglaterra. Asimismo, se aplicaron a una descripción laudatoria de la rama conservadora y federalista del republicanismo americano. Estas estrategias interpretativas permitieron utilizar el modelo estadounidense para justificar las formas antidemocráticas y centralistas que postulaba el moderantismo para el Estado español. Recurriendo a la historia del Common Law anglosajón, los moderados interpretaron que las leyes estadounidenses, lejos de ser la expresión universal de la modernidad política, eran el resultado de la evolución orgánica del derecho inglés. La conclusión racional era que las lecciones arrojadas por el éxito del constitucionalismo americano no debían mover a la imitación. Por el contrario, la durabilidad y eficacia de las leyes americanas demostraba, según los autores moderados, que cada pueblo debía codificar su constitución en base a sus propias tradiciones jurídicas $\mathrm{y}$ a sus formas de organización social. Esta conceptualización historicista permitía imaginar una modernidad constitucional propiamente hispánica y distintiva de la anglosajona.

En consecuencia con esta lectura, la Monarquía española y las repúblicas hispanoamericanas solo podían replicar el éxito estadounidense siendo parcialmente fieles al acervo jurídico y gubernativo legado por el Antiguo 
Régimen. Esto implicaba la consagración de ciertas formas de privilegio corporativo; la consolidación del poder social de la Iglesia; la exclusión de amplios sectores de población de los derechos políticos; y la primacía de los ejecutivos centralizados y fuertes frente a las instancias parlamentarias. Este fenómeno ideológico se vio también respaldado, como se ha mencionado, por el empeño que pusieron los intelectuales del moderantismo en subrayar los elementos elitistas y excluyentes del constitucionalismo estadounidense. La narrativa de los liberales conservadores se aplicó a construir un semblante heroico de los padres fundadores que se habian adscrito al ideal federalista frente a las tendencias democráticas. Esto comportó también una representación positiva de elementos que subrayaban el carácter aristocrático de la federación, y especialmente de los Estados sureños. En cualquier caso, los moderados instrumentalizaron la historia constitucional estadounidense como un espejo inverso que podia dar claves muy valiosas para organizar el liberalismo hispánico.

Por otro lado, las idealizaciones de la comunidad postimperial entre Estados Unidos y Gran Bretaña que aparecieron, tanto en el pensamiento progresista como en el moderado, tuvieron una dimensión performativa evidente en las estrategias de acercamiento bilateral adoptadas por la mente oficial española para generar una estructura de relaciones diplomáticas con las repúblicas hispanoamericanas. La imagen del aparente éxito de las relaciones angloamericanas estableció el objetivo de alcanzar una suerte de alianza comercial y geoestratégica que aprovechase los lazos de afinidad cultural e histórica con las antiguas dependencias para establecerse como un bloque de poder en el seno de la comunidad internacional. La politica exterior de España en las Américas estuvo determinada por estas aspiraciones durante todo el siglo XIX. La arquitectura normativa de la diplomacia del Atlántico anglosajón se normalizó como un factor importante a la hora de orientar los proyectos postimperiales de las élites españolas. Ciertamente, de nuevo, las visiones de lo global de progresistas y moderados se escindieron: los primeros aspiraron ante todo a un bloque hispánico de Estados parlamentarios que se constituyesen en una vanguardia del reformismo liberal en el mundo euroamericano; los moderados apostaron por una familia de Monarquias constitucionales con regímenes definidos por el poder de sus ejecutivos, por la centralización administrativa y por la ascendencia social de la Iglesia católica.

Enviado el (Submission Date): 01/02/2021

Aceptado el (Acceptance Date): 9/04/2021 